US Army Corps

of Engineers ${ }_{\otimes}$

Prepared for the U.S. Army Corps of Engineers, Portland District,

under an Interagency Agreement with the U.S. Department of Energy

Contract DE-AC05-76RL01830

\title{
Assessment of Fluctuating Reservoir Elevations Using Hydraulic Models and Impacts on Larval Pacific Lamprey Rearing Habitat in the Bonneville Pool
}

\section{FINAL REPORT}

RP Mueller

CL Rakowski

WA Perkins

MC Richmond

February 2015

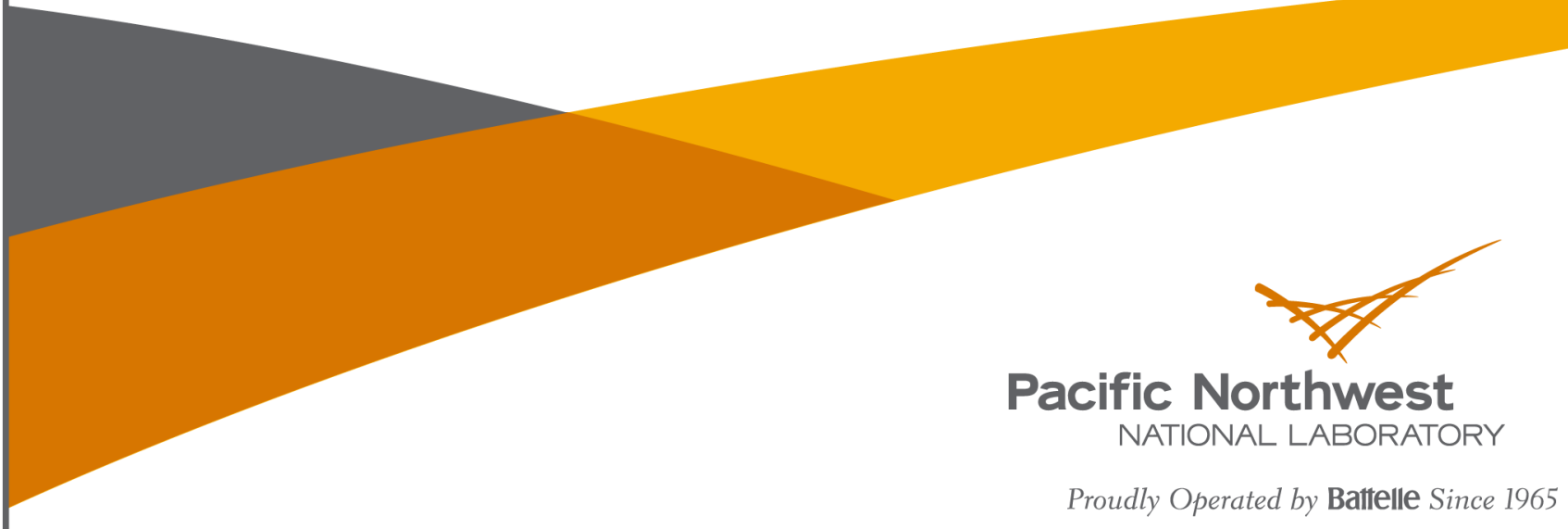




\title{
DISCLAIMER
}

This report was prepared as an account of work sponsored by an agency of the United States Government. Neither the United States Government nor any agency thereof, nor Battelle Memorial Institute, nor any of their employees, makes any warranty, express or implied, or assumes any legal liability or responsibility for the accuracy, completeness, or usefulness of any information, apparatus, product, or process disclosed, or represents that its use would not infringe privately owned rights. Reference herein to any specific commercial product, process, or service by trade name, trademark, manufacturer, or otherwise does not necessarily constitute or imply its endorsement, recommendation, or favoring by the United States Government or any agency thereof, or Battelle Memorial Institute. The views and opinions of authors expressed herein do not necessarily state or reflect those of the United States Government or any agency thereof.

\author{
PACIFIC NORTHWEST NATIONAL LABORATORY \\ operated by \\ BATTELLE \\ for the \\ UNITED STATES DEPARTMENT OF ENERGY \\ under Contract DE-AC05-76RL01830
}

Printed in the United States of America

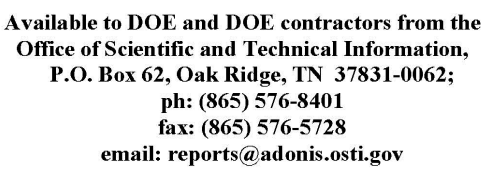

Available to the public from the National Technical Information Service, U.S. Department of Commerce, 5285 Port Royal Rd., Springfield, VA 22161 ph: (800) 553-6847 fax: $(703) 605-6900$

email: orders@ntis.fedworld.gov

online ordering: http://www.ntis.gov/ordering.htm

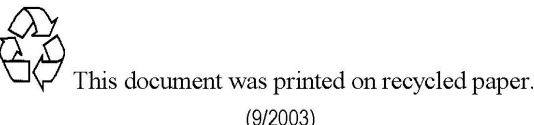

(9/2003) 


\section{Assessment of Fluctuating Reservoir Elevations Using Hydraulic Models and Impacts on Larval Pacific Lamprey Rearing Habitat in the Bonneville Pool}

FINAL REPORT

RP Mueller

CL Rakowski

WA Perkins

MC Richmond

February 2015

Prepared for

U.S. Army Corps of Engineers, Portland District

Under an Interagency Agreement with

the U.S. Department of Energy

Contract DE-AC05-76RL01830 



\section{Preface}

This study was conducted by the Pacific Northwest National Laboratory (PNNL) for the U.S. Army Corps of Engineers, Portland District (CENWP), to support research and management decisions about potential impacts on larval Pacific lamprey rearing habitat in the Bonneville pool of the Columbia River. The CENWP technical leads were Sean Tackley and Nathan Zorich and the PNNL project manager was Robert Mueller (509-371-7229). The data are archived at PNNL offices in Richland, Washington. This final report is a project deliverable (PNNL Project No. 65645). PNNL is operated by the Battelle Memorial Institute for the U.S. Department of Energy under Contract DE-AC05-76RL01830.

A suggested citation for the report is: Mueller, RP, CL Rakowski, WA Perkins and MC Richmond. 2014. Assessment of Fluctuating Reservoir Elevations Using Hydraulic Models and Impacts on Larval Pacific Lamprey Rearing Habitat in the Bonneville Pool. PNNL-23876, final report submitted to the U.S. Army Corps of Engineers, Portland District, Portland, Oregon, by Pacific Northwest National Laboratory, Richland, Washington. 



\section{Summary}

This report presents the results of a modeling assessment of potential Pacific lamprey (Entosphenus tridentatus) larval habitat that may be impacted by dewatering of the major tributary delta regions in the Bonneville pool of the Columbia River. This assessment was conducted by the Pacific Northwest National Laboratory (PNNL) for the U.S. Army Corps of Engineers Portland District (CENWP). The goal of the study was to provide baseline data about how the regions of interest would potentially be impacted at three river flows (10, 50, and 90 percent exceedance flow) for four different forebay elevations at Bonneville Dam (minimum operating pool [MOP], MOP $+1 \mathrm{ft}, \mathrm{MOP}+2 \mathrm{ft}$, and high pool). Impacts of unsteady flows at The Dalles Dam and changing forebay elevation at Bonneville Dam for a 2week period were also assessed. The area of dewatered regions was calculated by importing data output from a two-dimensional, depth-averaged numerical hydraulic model (MASS2) into a geographic information system (GIS) and then calculating the change in inundated area near tributary deltas for the four Bonneville forebay surface elevations.

From the modeled output we determined that the overall change in area is less sensitive to elevation changes during higher river discharges. Changing the forebay elevation at Bonneville Dam and the resulting impact on total dewatered regions was greater at the lowest modeled river flow (97 kcfs) and showed the greatest variation at the White Salmon/Hood River delta regions followed by the Wind, Klickitat, and the Little White Salmon rivers.

Larval lampreys may be susceptible to rapid water dewatering events which may lead to desiccation if water levels are held for prolonged periods. To understand how inundation might change on a daily and hourly basis, the hydraulic model was run for unsteady conditions for an example 2-week period in 2002 when water-surface elevation fluctuations had a wide range of values and compared to 2014 conditions. The water-surface elevation in the reservoir closely follows that of the Bonneville Dam forebay with rapid changes of 1 to $2 \mathrm{ft}$ possible. The data show that 2.5 -ft variation in water-surface elevation occurred during this period in 2002 and a 3.7-ft change occurred in 2014. The durations of these changes were highly variable and generally did not stay constant for more than a 5-hr period. 


\section{Acknowledgments}

Funding for this project was provided by the U.S. Army Corps of Engineers (USACE), Portland District. Sean Tackley and Nathan Zorich were the USACE technical leads. The authors thank Laurie Ebner at USACE for providing valuable insights on past and current hydrologic conditions in the lower Columbia River and John Serkowski at PNNL for processing bathymetric data. 


\section{Abbreviations}

2D

BiOp

CENWD

CENWP

DART

$\mathrm{ft}$

GIS

ha

in.

kcfs

$\mathrm{m}$

MASS2

MOP

NAVD88

NGVD 29

Lampreys

USFWS

USGS

WSE

two-dimensional

biological opinion

U.S. Army Corps of Engineers Northwestern Division

U.S. Army Corps of Engineers, Portland District

Data Access in Real Time

foot, feet

geographic information system

hectare(s)

inch(es)

thousand cubic feet per second

meter(s)

Modular Aquatic Simulation System in 2 Dimensions

minimum operating pool

North American Vertical Datum of 1988

National Geodetic Vertical Datum of 1929

Pacific lamprey

U.S. Fish and Wildlife Service

U.S. Geological Survey

water-surface elevation 



\section{Contents}

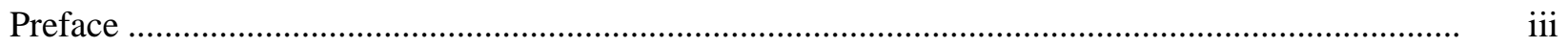

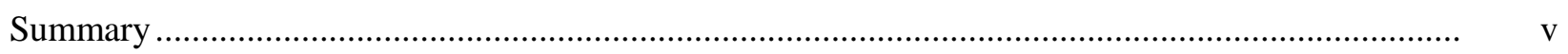

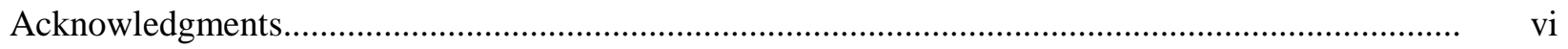

Abbreviations …................................................................................................................... vii

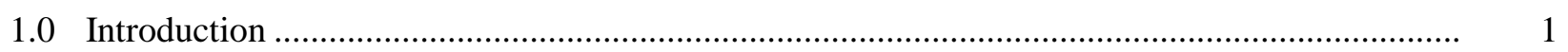

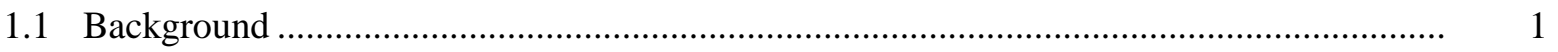

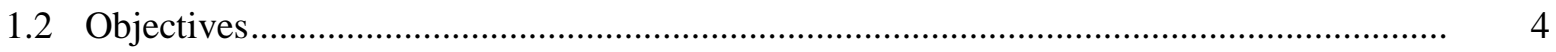

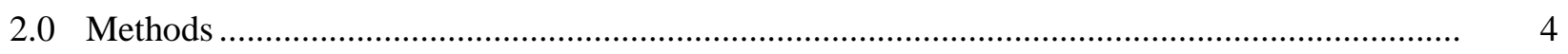

2.1 MASS2 Model — General Description ............................................................................. 4

2.2 Existing Bathymetric Data ......................................................................................... 4

2.3 MASS2 for the Bonneville Pool.................................................................................. 5

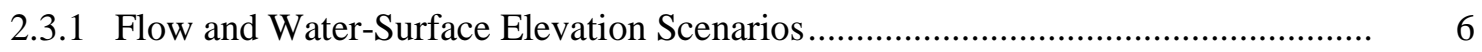

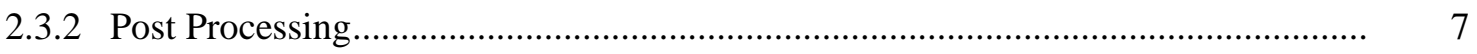

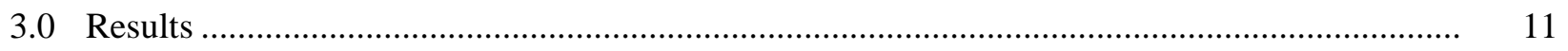

3.1 Effect of Changing Forebay Elevation ........................................................................... 11

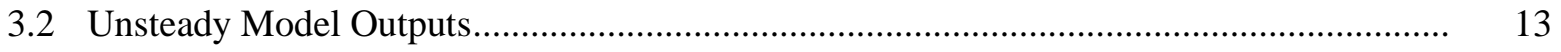

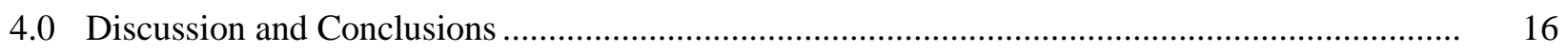

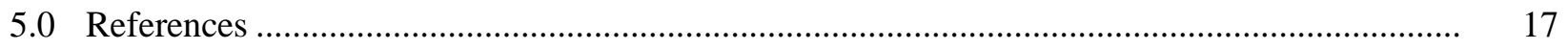

Appendix A - Modeled Riverbed Elevations …................................................................................ A.1 


\section{Figures}

1. Aerial imagery illustrating change in bar region at the mouth of the Wind River from 1993 and 2011

2. Previous MASS2 computational mesh and bathymetric data near the Little White Salmon River.

3. Overview map of Zones 1-4 and location within the Bonneville pool on the Columbia River.

4. Little White Salmon, Zone 1..............................................................................................

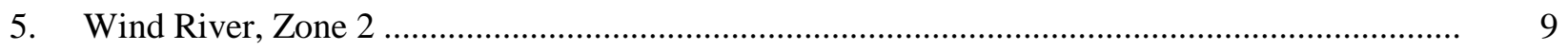

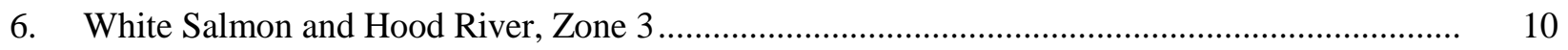

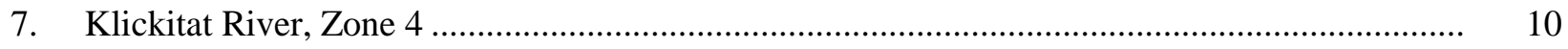

8. Change in hectares of inundation in the areas of interest for a river flow of $97 \mathrm{kcfs}$.................. 11

9. Change in hectares of inundation in the areas of interest for a river flow of $135 \mathrm{kcfs}$................. 12

10. Change in hectares of inundation in the areas of interest for a river flow of $291 \mathrm{kcfs} . . . . . . . . . . . . . . . \quad 12$

11. Unsteady MASS2 boundary conditions for Bonneville Dam WSE and The Dalles Dam hourly flow from February 1 to 15 in 2002 ......................................................................... 14

12. The Dalles Dam flows and Bonneville Dam forebay WSE for February 1 to 15 in 2014............ 15

\section{Tables}

1. Bonneville Dam forebay elevations modeled.

2. Total area used for MASS 2 analysis within four tributary delta regions in the Bonneville Pool.... 


\subsection{Introduction}

In regard to the 2008 Columbia Basin Fish Accords and the U.S. Army Corps of Engineers Pacific Lamprey Passage Improvements Implementation Plan (ACOE 2009), this work addresses a lack of knowledge regarding concerns raised by tribal agencies, the U. S. Fish and Wildlife Service, and the Northwest Power Planning Council in Section 7.5F of the 1994 Columbia River Basin Fish and Wildlife Program (NPPC 1994), related to the effects of Federal Columbia River Power System projects and operations on Pacific lamprey (Entosphenus tridentatus) in the Columbia and Snake rivers. While larval rearing and hydrosystem operations were not addressed specifically in either document, there is much regional interest in attaining a better understanding of how reservoir operations might affect main-stem rearing habitat. The tribes and other agencies are pursuing propagation of lampreys and have had success in early life-stage rearing. The goal is to increase populations in river systems that have had poor adult returns and to out-plant larvae in streams when they reach a sustainable age. These out-plantings and subsequent habitat occupation in lower river reaches and river mouth section will be important to the survival of lampreys and their development to the macrophthalmia life stage. In addition, all naturally occurring juvenile production could be influenced by reservoir operations, particularly the Bonneville pool, because conservation actions have mainly been focused on tributary passage and habitat restoration. Other habitat and passage improvements that have occurred in recent years include the following:

- Translocation efforts by tribes as a means of supplementing the population of upstream migrants that successfully navigate the hydrosystem.

- U.S. Army Corps of Engineers Northwestern Division efforts to improve habitat connectivity and provide access to spawning areas through upstream passage improvements at dams.

- Work by the tribes and others in tributaries to provide passage at low-head diversion structures, replacing culverts, and other habitat restoration projects.

It is critical to know how larval lampreys use the areas upstream and downstream of dams to understand the importance of these areas to long-term population viability. At present, little specific information is available regarding the numbers of lamprey larvae that use these areas, the timing and duration of use, whether specific locations are used, and how hydrosystem operations can affect larval lamprey rearing areas. General information about larval lamprey distribution is slowly becoming available throughout the region; however, it remains unknown how dewatering of rearing habitat affects the survival of lampreys. The impacts on lampreys from changing river flows and resulting changes in water-surface elevation (WSE) in the lower Columbia River are also unknown. A better understanding of the potential impacts can help inform how resource managers regulate reservoir and tailwater levels and, in turn, help to minimize any negative impacts on lamprey populations.

\subsection{Background}

Pacific lamprey have a complex life history that includes a 3- to 7-year larval (i.e., ammocoete) phase, a migratory juvenile (i.e., macrophthalmia) phase, and an adult phase. Larvae and juveniles are strongly associated with stream and river sediments. Larvae live burrowed in stream and river sediments for up to 7 years after hatching, where they filter feed on detritus and organic material. Larvae metamorphose into juveniles from July to December and migrate downstream to the Pacific Ocean. The timing, duration, and habitat use of the larval life stages are poorly understood. For lampreys, the 
majority of the information about the habitat preference of larvae comes from Columbia River basin tributary systems. Lamprey larvae are known to occur in shallow stream sediments, but their use of comparatively large river habitats in relatively deeper areas is poorly understood. Sea lamprey (Petromyzon marinus) larvae have been documented in deepwater habitats in tributaries of the Great Lakes, the St. Mary's River, and near the mouths of rivers. The occurrence of larval lampreys at hydropower facilities has been reported anecdotally; they have been primarily observed in downstream bypass facilities, impinged on downstream screens, or during dewatering events (Moser et al. 2014). However, recent studies indicate that larval lampreys occupy main-stem areas of the Columbia and Willamette Rivers, including reservoirs created by hydropower facilities (Jolley et al. 2012a, b). Various life stages of larval lampreys are known to inhabit the lower sections and mouths of Columbia River tributaries during their transformation to macropthalmia. These regions include sand and mud flats near the major tributary delta regions, which may have expanded in recent years due to sediment deposition. Lampreys are likely to use these shallow-water habitats throughout the year (Jolley et al. 2012a, b). During the spring freshet when reservoir levels are at their maximum these habitats are largely submerged; however water levels often fluctuate during the year due to several factors. Regions just below the main-stem dams are most susceptible to water level changes resulting from a change in discharge. It is unknown whether the larval lampreys inhabiting the shallow delta regions are able to vacate their burrows and move to deeper water as the water level recedes. The major tributary sediment loads can alter the delta regions over time and flows in the Columbia River do not scour these protected tributary delta regions and are likely impacted by wind/wave forces. As such, the delta region continues to grow and change shape as can be seen by looking at satellite imagery near the mouth of the Wind River over an 18-year period (Figure 1).

To determine possible negative impacts (dewatering of rearing habitats) during normal reservoir pool fluctuations, PNNL used a two-dimensional (2D) depth-averaged river hydrodynamics model, Modular Aquatic Simulation System in 2 Dimensions (MASS2; Perkins and Richmond 2004). This model has been extensively applied in the Bonneville pool—most recently by Rakowski et al. (2010). MASS2 capabilities include wetting and drying of the river channel which allows for the quantification of changes in inundation in response to Bonneville Dam forebay elevation and river flows. 

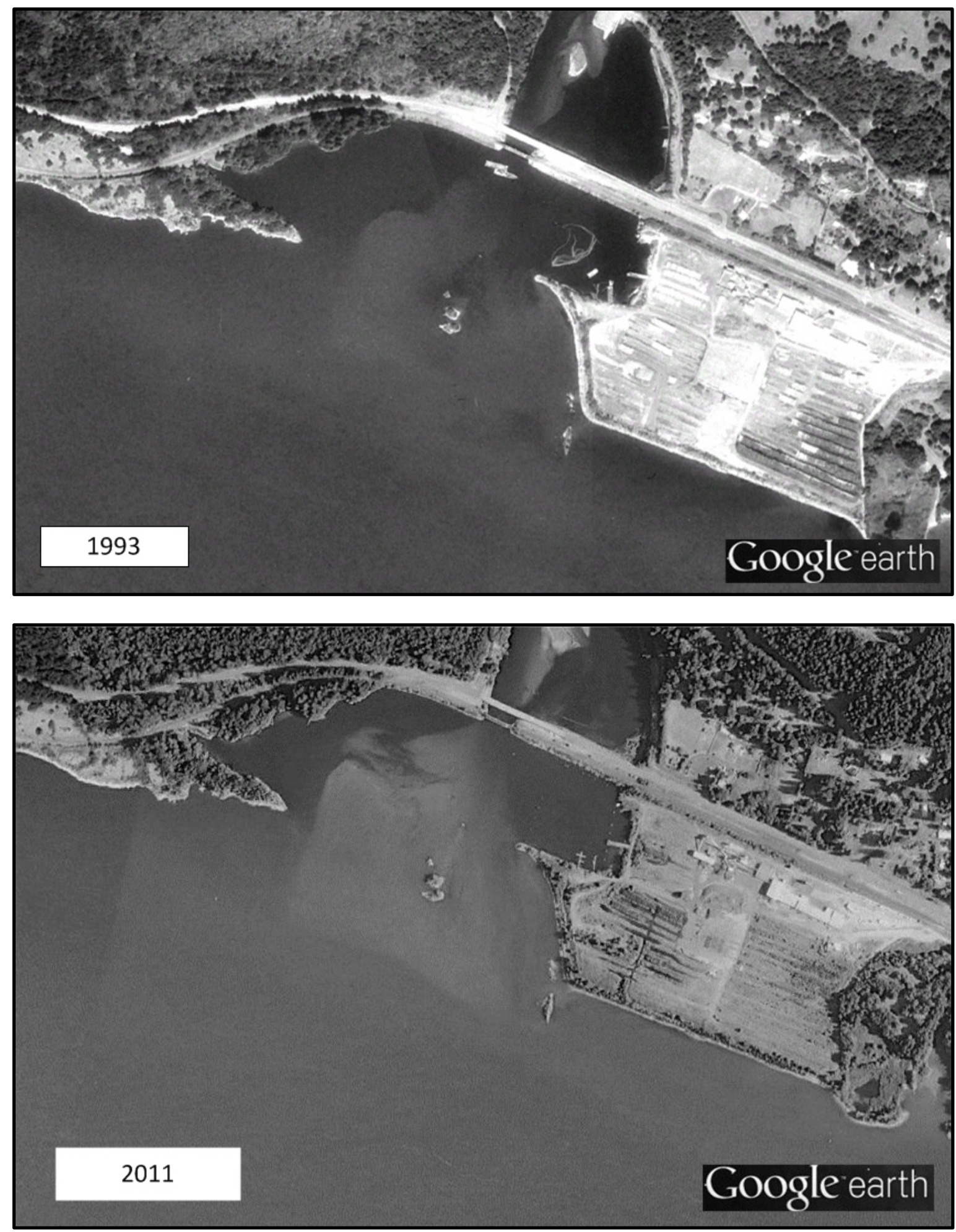

Figure 1. Aerial imagery illustrating change in bar region at the mouth of the Wind River from 1993 (top) and 2011 (bottom). 


\subsection{Objectives}

The purpose of the study documented herein was to identify larval lamprey rearing areas that might be most vulnerable to changes in pool elevation as a result of hydrosystem operations.

Researchers at Pacific Northwest National Laboratory (PNNL) performed model simulations on four forebay elevations (minimum operating pool [MOP], $\mathrm{MOP}+1 \mathrm{ft}, \mathrm{MOP}+2 \mathrm{ft}$, and high pool) and river discharges corresponding to three flow exceedance values $(10,>50$, and $90 \%)$. The exceedance flows were calculated for June 1 through November 30 during a 10-year period. The 10\% exceedance flow means that river flows were larger than that discharge only $10 \%$ of the time. Unsteady conditions were simulated using historical operations data to compute dewatering rates and the minimum expected WSE that could occur within the Bonneville pool.

\subsection{Methods}

\subsection{MASS2 Model - General Description}

The depth-averaged numerical hydraulic model used in this study-MASS2 — was developed at PNNL. The model has been successfully applied to a variety of river and estuarine flows (Richmond et al. 1999a; Rakowski and Richmond 2001, 2003; Rakowski et al. 2010; Niehus et al. 2014), water quality (Richmond et al. 1999a, b, 2000; Kincaid et al. 2001), and aquatic habitat assessments (McMichael et al. 2003; Perkins et al. 2004; Hanrahan et al. 2007). Specific to the needs of this project, MASS2 has been previously used to model all reservoirs in the Lower Columbia and Snake Rivers, including Bonneville pool.

The MASS2 model is formulated using the general finite-volume principles described by Patankar (1980). The model uses a structured multi-block scheme using a curvilinear computational mesh. Spasojevic and Holly (1990) give an example of a 2D model of this type. The momentum and mass conservation equations are coupled with a variation of the Patankar (1980) SIMPLE algorithm extended to shallow-water flows by Zhou (1995). In MASS2, Zhou's method has been applied to orthogonal curvilinear coordinates. In this method, the continuity equation is discretized and solved for a depth correction in lieu of the pressure correction in the original SIMPLE algorithm. The solution to the depthcorrection equation is used to correct the estimated velocity from the solution of the momentum equations. A portion of the depth correction is used to adjust depth. An in-depth description of the underlying theory for MASS2 is provided by Perkins and Richmond (2004).

\subsection{Existing Bathymetric Data}

Existing bathymetric data from a previous hydraulic modeling study (Rakowski et al. 2010) was used as a starting point. However, the existing bathymetry collected in 1997 had the following limitations:

- It covered the main channel but had little to no coverage in shallow areas such as the tributary river confluences of interest for this study.

- In the Bonneville pool (far from the dams), the bathymetry was typically based on 500-ft transects across channel with 100-ft spacing in the navigation channel. 
The U.S. Fish and Wildlife Service (USFWS) sent PNNL a limited set of data points for water depth from larval lamprey surveys conducted in 2013. The data points were useful for filling in some of the unknown water depths at the tributary delta regions where existing bathymetric data were lacking in coverage. Figure 2 illustrates sampling points obtained at the mouth of the Little White Salmon River. These depth data were incorporated into the computational mesh used for the model runs. For the unsurveyed regions, we used the existing data and made assumptions about the remaining regions based on extrapolation or assuming regions were too shallow to sample (i.e., $<3-\mathrm{ft}$ water depth).

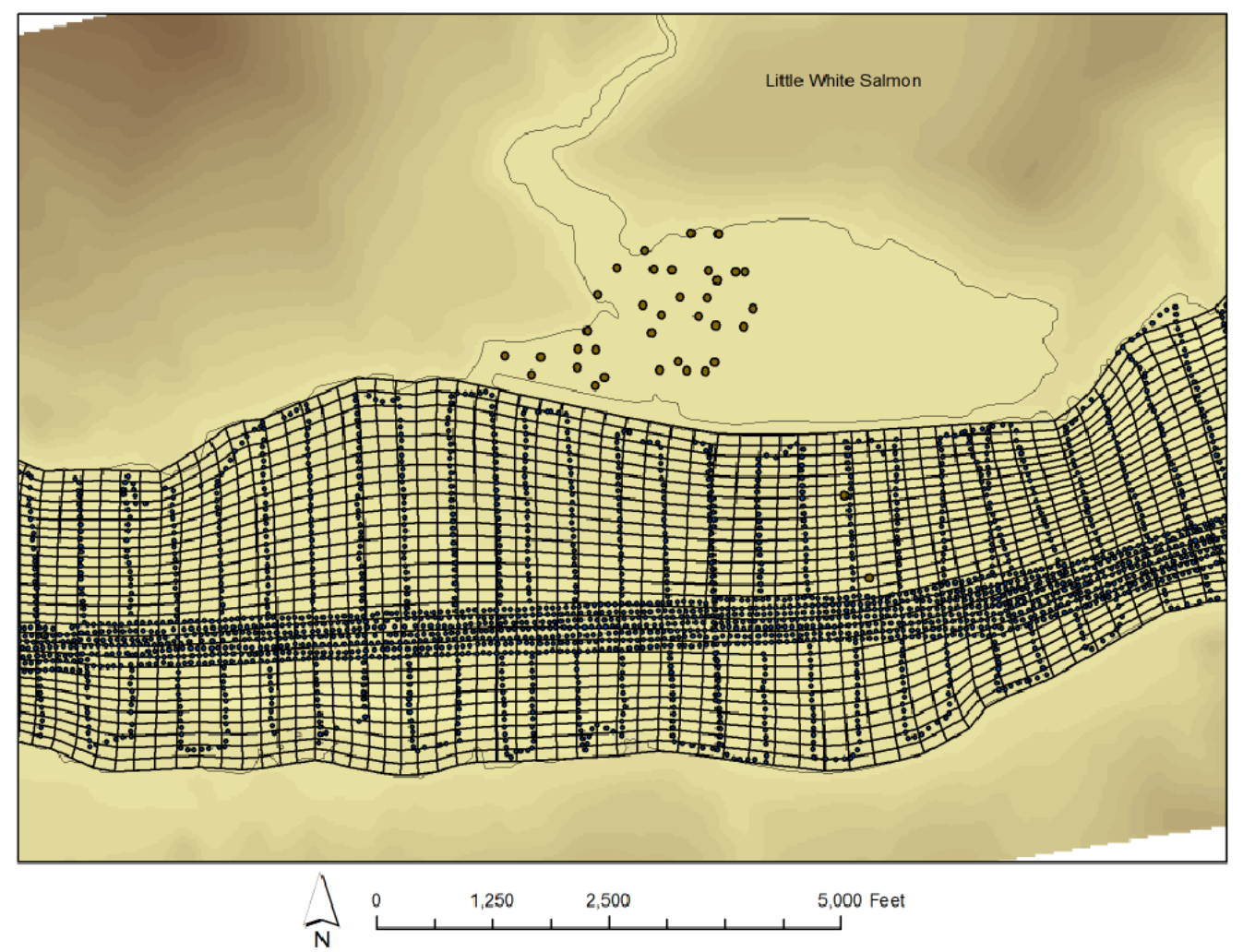

Figure 2. Previous MASS2 computational mesh and bathymetric data near the Little White Salmon River.

\subsection{MASS2 for the Bonneville Pool}

MASS2 is a 2D depth-averaged hydraulic model that can directly provide spatially distributed habitat and affected habitat estimates (Perkins et al. 2004). In this initial work, MASS2 was used to quantify the area changed to due to channel inundation. However, MASS2 can also be used for more detailed habitat estimates based on depth and velocity criteria.

A new computational mesh was created for the Bonneville pool for use with the MASS2 model. The mesh, composed of about 800,000 cells, had about a 30-ft horizontal resolution extending from the Bridge Islands (just below The Dalles Dam) to below the Bridge of the Gods. The model was run for 12 steadystate cases and a 2-week unsteady flow scenario. MASS2 was configured with inflow discharge specified at The Dalles Dam and a WSE at the downstream boundary. The Bonneville Dam forebay elevation was used for this boundary. Resistance to flow from channel roughness was modeled using Manning's n values calibrated in previous model applications. 
The river-channel geometry used in the MASS2 model was developed from a bathymetric surface created for the Columbia River Hydraulic Influence project (Rakowski et al. 2010). While good survey coverage was available near the dams and locks, the majority of the Bonneville pool bathymetry was developed from a 1997 navigation-channel survey. This survey emphasized the deepest part of the channel, so the shallows along the shorelines were not well represented. To improve the bathymetric surface in the shallow-water areas, the original surface was modified as follows:

- Additional depth-to-bottom measurements obtained from lamprey studies conducted by USFWS were converted to bottom elevations and incorporated into the bathymetric surface model. These data superseded any existing data.

- Elevation contours were added based on underwater features (e.g., sandbars) visible in aerial photos. These features were generally no deeper than $4 \mathrm{~m}$ below the surface.

- Elevation contours were added based on subjective interpretation of existing point-survey data. This was done in areas where point data were relatively sparse, but particularly along the pool shores.

The original survey data sets, plus the new point and line data, were then interpolated to a 50-ft $\mathrm{x}$ 50 -ft square grid to create the bathymetry surface. This updated bathymetric surface was used in the computational mesh for the hydraulic model.

\subsubsection{Flow and Water-Surface Elevation Scenarios}

To establish a realistic starting point for determining MOP measured at Bonneville Dam we queried the Data Access in Real Time (DART) database and found that lower end of MOP for the previous 5 years was $\sim 70 \mathrm{ft}$. We did not do any model runs with elevations lower than this value. Table 1 lists the Bonneville Dam forebay elevations that were modeled. The river flows chosen were based on exceedance flows. Ten-year (2004-2013) average exceedance flows at 10\%, 50\% (median), and 90\% were determined from data collected by the U.S. Geological Survey (USGS) gage located downstream of The Dalles Dam for the period June 1 to Nov. 30. These flows were 291.4, 135.7, and $97.45 \mathrm{kcfs}$ (thousand cubic feet per second), for the 10,50, and $90 \%$ exceedance flows, respectively. No tributary flows were included as the predominant control on the WSE was main-stem flow and the forebay elevation at Bonneville Dam.

Table 1. Bonneville Dam forebay elevations modeled.

\begin{tabular}{cc}
\hline Condition & Forebay elevation $(\mathrm{ft})$ \\
\hline MOP & 71.5 \\
MOP+1 & 72.5 \\
MOP+2 & 73.5 \\
High Pool & 76.5 \\
\hline
\end{tabular}

Initially, an elevation of $76.5 \mathrm{ft}$ was specified as the "average" pool elevation in the Bonneville Dam forebay. From discussions with Dr. Laurie Ebner (U.S. Army Corps of Engineers, Portland District [CENWP] Hydraulic Design), it was determined that this "average" elevation of $76.5 \mathrm{ft}$ was NAVD88 (North American Vertical Datum of 1988), rather than $73.2 \mathrm{ft}$ of NGVD 29, the datum used for the MOP reference. This pool elevation is at the higher end of the regular forebay fluctuations. All of the 
Bonneville bathymetry data were NGVD 29 (National Geodetic Vertical Datum of 1929), consistent with CENWP guidelines. Because the average pool was very similar to the $\mathrm{MOP}+2 \mathrm{run}$, the higher pool elevation model was used to envelope the larger range of WSEs in the Bonneville pool and used as the reference to compare dewatered area. A 2-week period was used for the unsteady run. Hourly discharge data from The Dalles Dam and hourly Bonneville Dam WSEs were used as the model boundary conditions.

\subsubsection{Post Processing}

The study regions chosen for the post processing of model results were centered on larval lamprey rearing regions previously documented by deepwater electroshocking surveys in the Bonneville Dam pool of the Columbia River (Jolley et al. 2012a, b, 2011). While other nearshore rearing regions may exist and could be affected by inundation changes, the current modeling effort only looked at likely larval lamprey habitat, and the analysis was restricted to the areas near and just downstream of the major tributary confluences (Figure 3). The sampling areas were delineated near each tributary inflow (Figure 3 through Figure 6). These figures also show locations where water depths were obtained from prior USFWS surveys and incorporated into the bathymetric surface. Changes in inundated area relative to that modeled with the 76.5-ft Bonneville Dam forebay were compared for each flow scenario for changes in forebay elevation. Because all potential dewatered areas of this study were shallow and near tributaries, they were assumed to have optimal (Type 1 - preferred habitat with fine sediment and organic matter) or usable (Type 2 - usable habitat with a combination of fine and coarse sediment) sediments for larval lamprey rearing.

After MASS2 was run and results were saved for each flow and WSE at Bonneville Dam, a script in GRASS (GIS), was used to extract the changes in inundated area and changes in forebay elevation for four areas of interest. These areas included the delta regions of the Little White Salmon (Zone 1), Wind River (Zone 2), White Salmon and Hood River (Zone 3), and the Klickitat River (Zone 4). The total areas for each of the zones ranged from 2,226.7 ha for the Little White Salmon to 14,790.7 ha for the Little White Salmon and Hood River (Table 2). The zones were mostly skewed downstream of the tributary mouths, which would be the likely deposition region for fine-grained sediments of debris fans. The connection of the Little White Salmon River to the main-stem Columbia is a narrow opening at the west end of the Drano Lake. We did not assess impacts within Drano Lake and no evidence of a debris fan was apparent at the interface with the Columbia River from the model runs. 
Table 2. Total area used for MASS 2 analysis within four tributary delta regions in the Bonneville Pool.

\begin{tabular}{lc}
\hline \multicolumn{1}{c}{ Location } & Total Area (ha) \\
\hline Little White Salmon (Zone 1) & $2,226.7$ \\
Wind (Zone 2) & $10,879.0$ \\
White Salmon/Hood (Zone 3) & $14,790.7$ \\
Klickitat (Zone 4) & $5,546.3$ \\
\hline
\end{tabular}

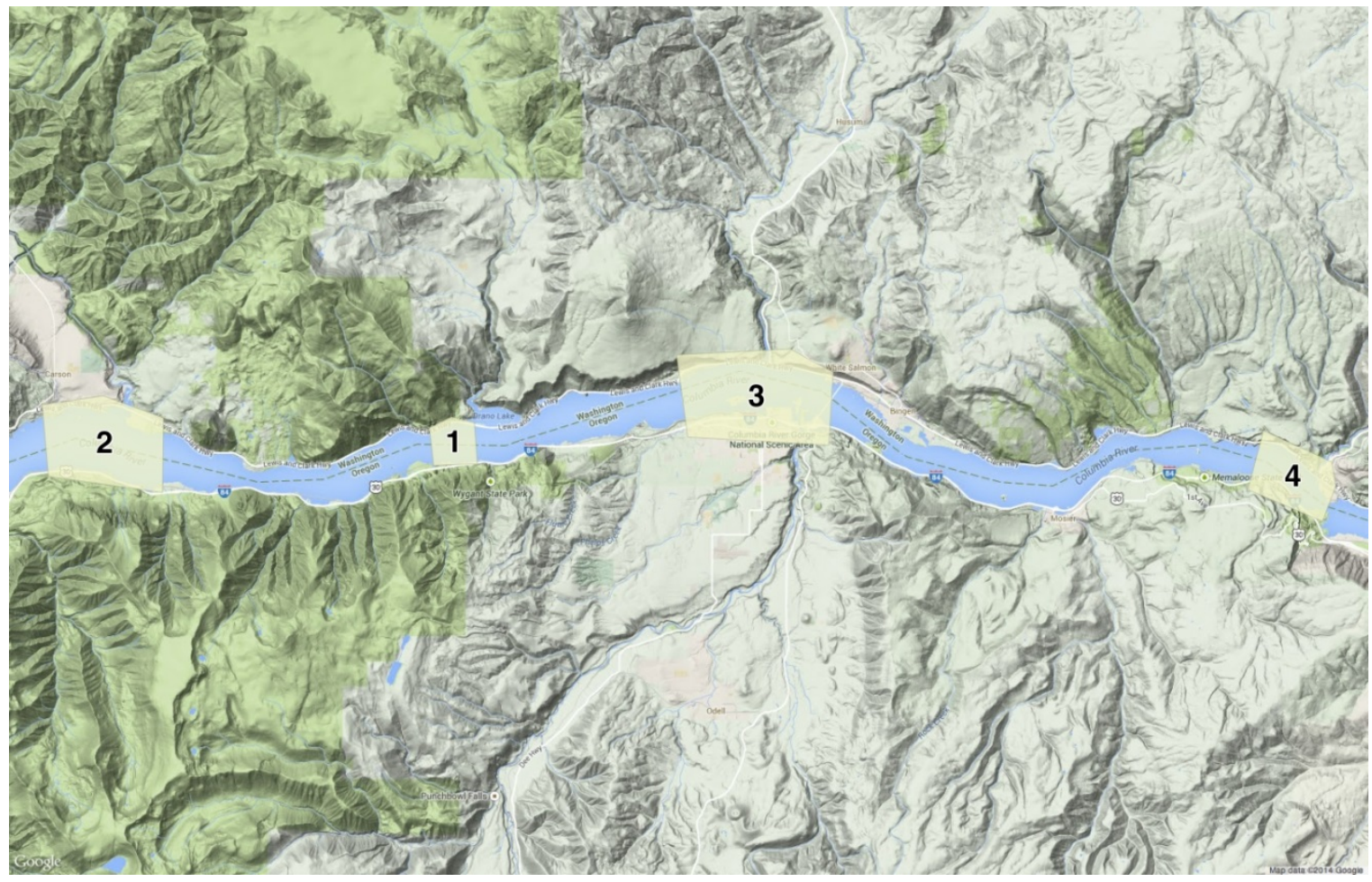

Figure 3. Overview map of Zones 1-4 and their location within the Bonneville pool on the Columbia River. 


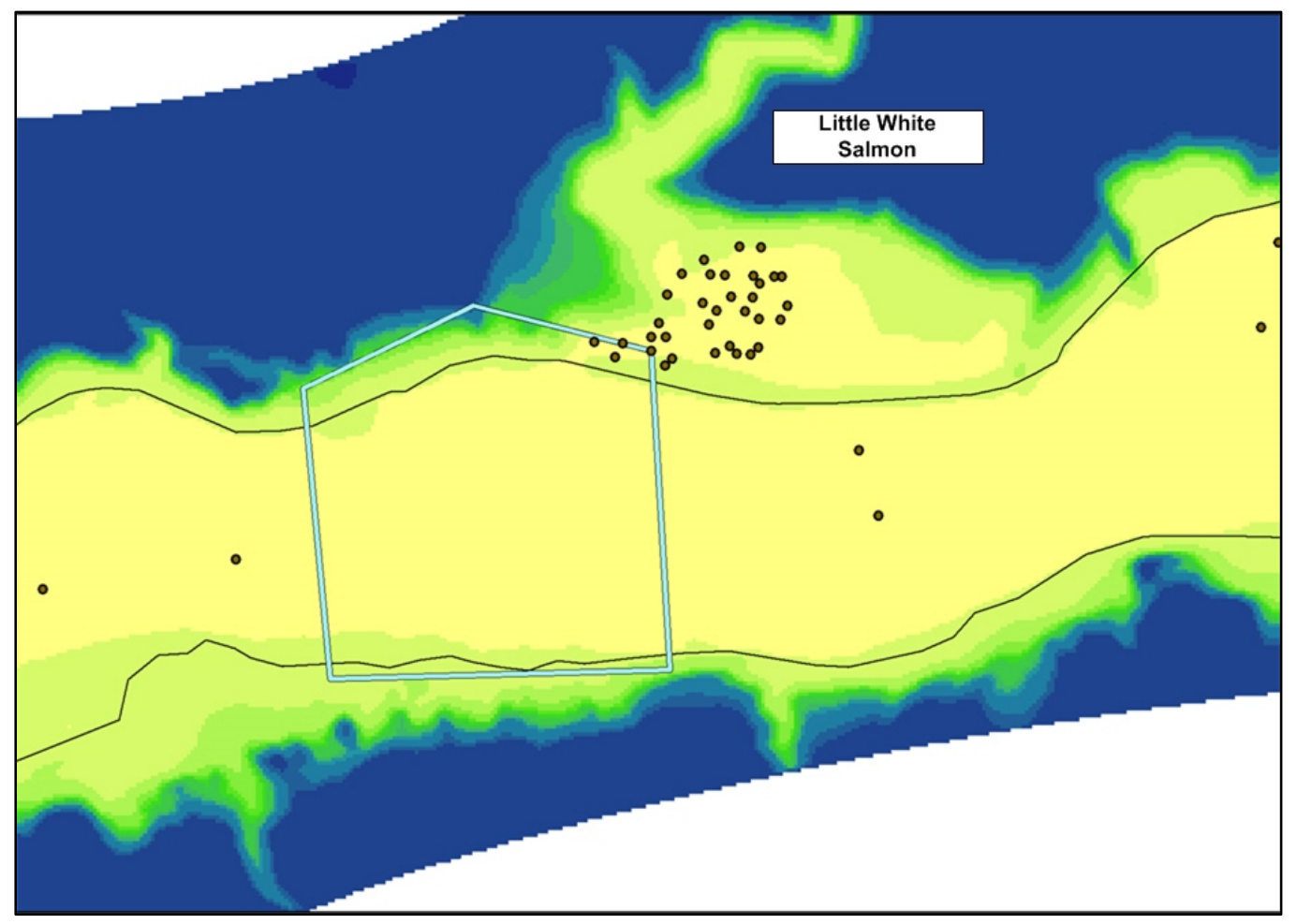

Figure 4. Little White Salmon, Zone 1 (polygon region outlined and circular dots indicate sampling locations from prior larval lamprey surveys where water depths were obtained).

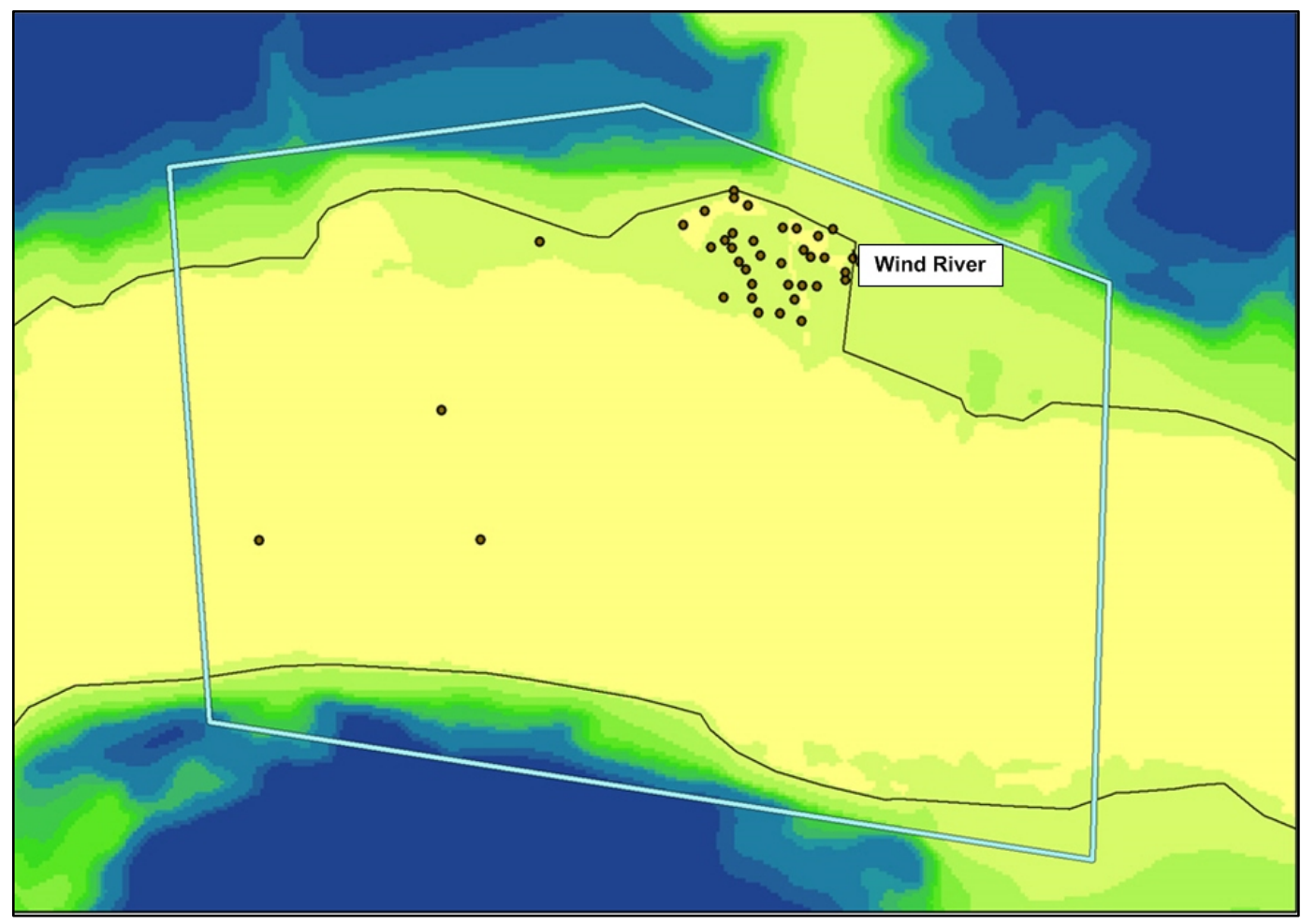

Figure 5. Wind River, Zone 2 (polygon region outlined and circular dots indicate sampling locations from prior larval lamprey surveys where water depths were obtained). 


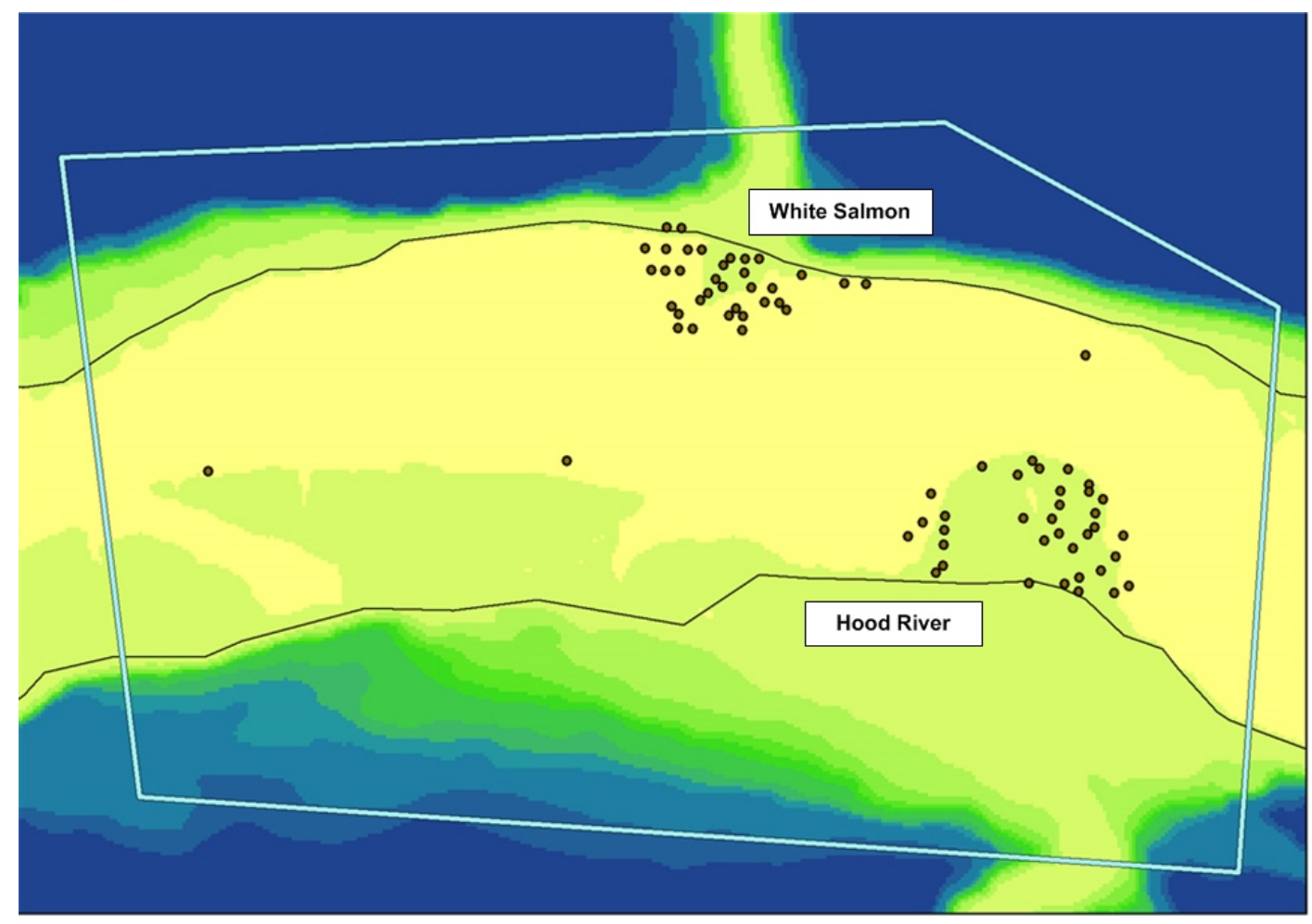

Figure 6. White Salmon and Hood River, Zone 3 (polygon region outlined and circular dots indicate sampling locations from prior larval lamprey surveys where water depths were obtained).

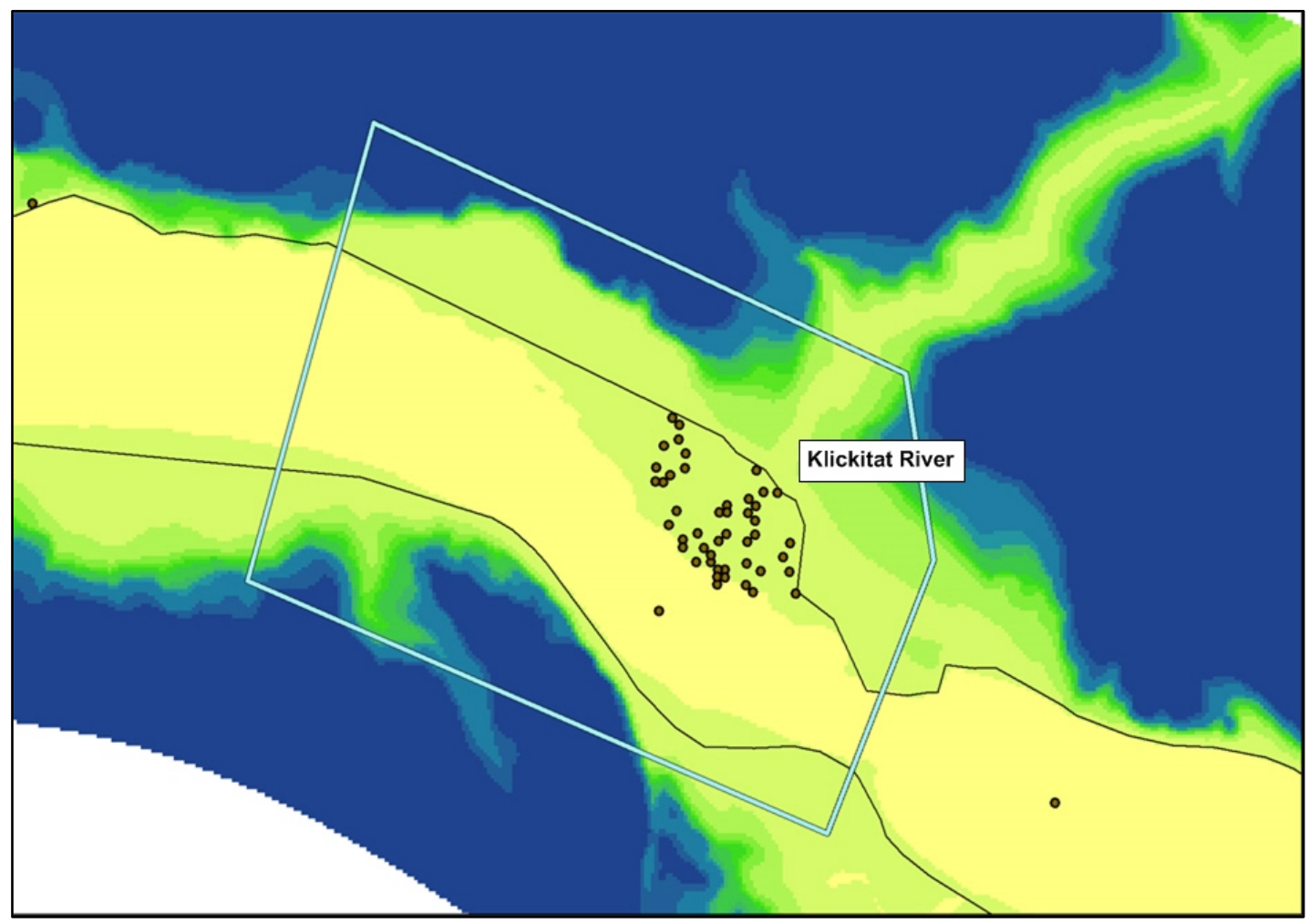

Figure 7. Klickitat River, Zone 4 (polygon region outlined and circular dots indicate sampling locations from prior larval lamprey surveys where water depths were obtained). 


\subsection{Results}

\subsection{Effect of Changing Forebay Elevation}

The impact of the changes to forebay elevation was tested at three different flows by holding the flow constant and adjusting the Bonneville Dam forebay elevation. The change in area for the selected "zones of interest" is shown graphically as the difference in hectares from the inundated area at a forebay elevation of $76.5 \mathrm{ft}$ (Figure 7 through Figure 9). Because the nearshore bathymetry data were sparse in these areas of interest, these data should be viewed as qualitative, not quantitative. The percent of dewatered area for a river flow of $97 \mathrm{kcfs}$ at the three Bonneville Dam forebay elevations tested shows the greatest difference in total area at Zone 3 (White Salmon/Hood Rivers), from 28.4 ha at MOP+2 to 60.7 ha at MOP or a 32.3-ha reduction. Zones 2 and 4 had reductions of 15.8 and 13.2 ha and the least impacted was Zone 1 at 2.7 ha. Zone 3 also had the largest difference in dewatered area for the three forebay elevations at flows of 135 and 291 kcfs followed by Zones 2, 4 and 1 (Figures 9 and 10).

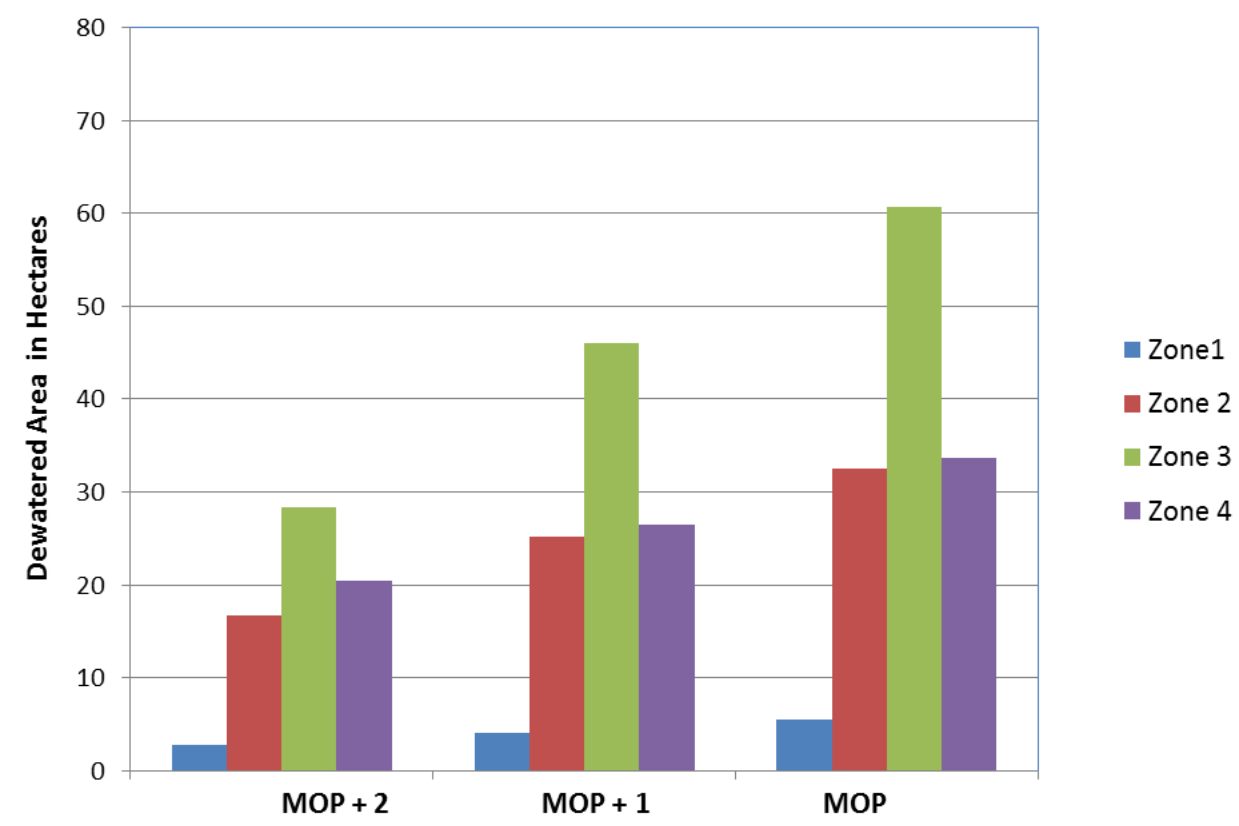

Figure 8. Change in hectares of inundation in the zones of interest for a river flow of $97 \mathrm{kcfs}$. 


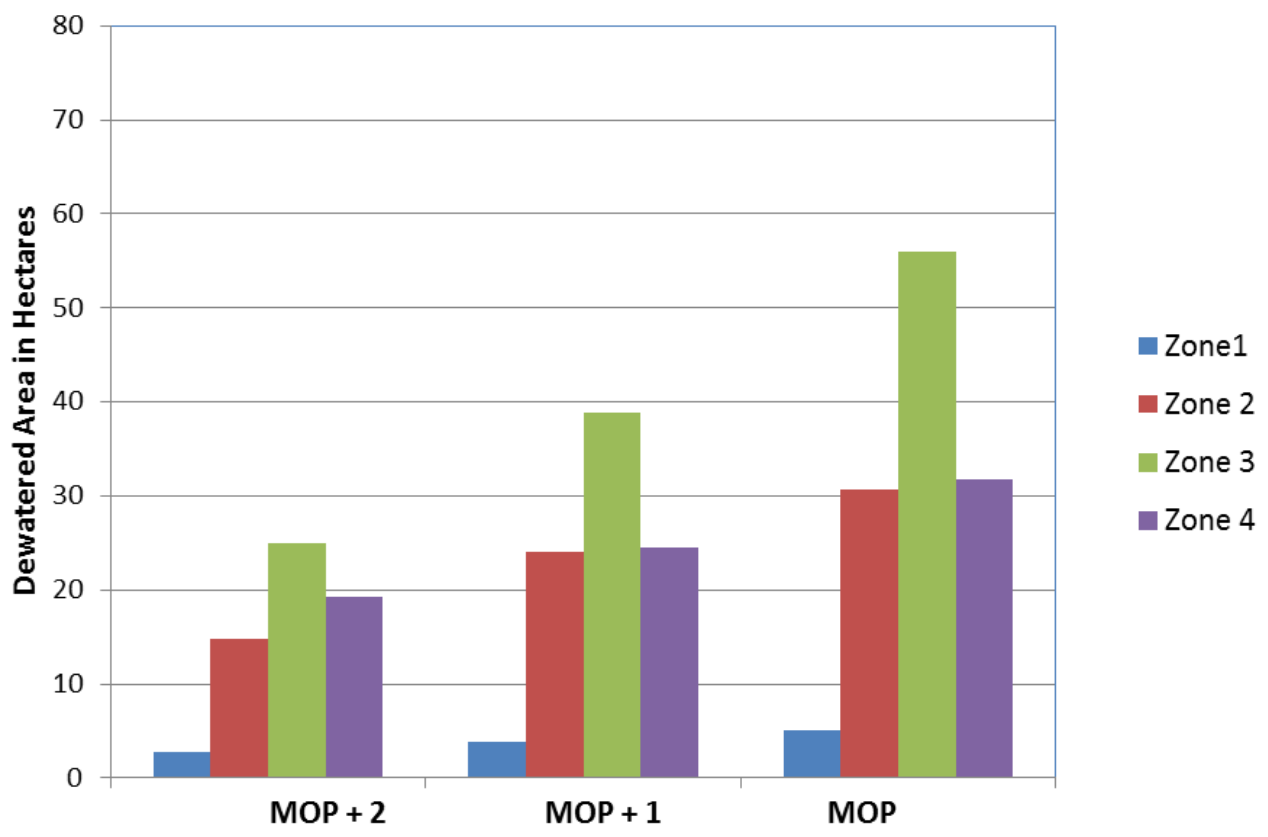

Figure 9. Change in hectares of inundation in the zones of interest for a river flow of 135 kcfs.

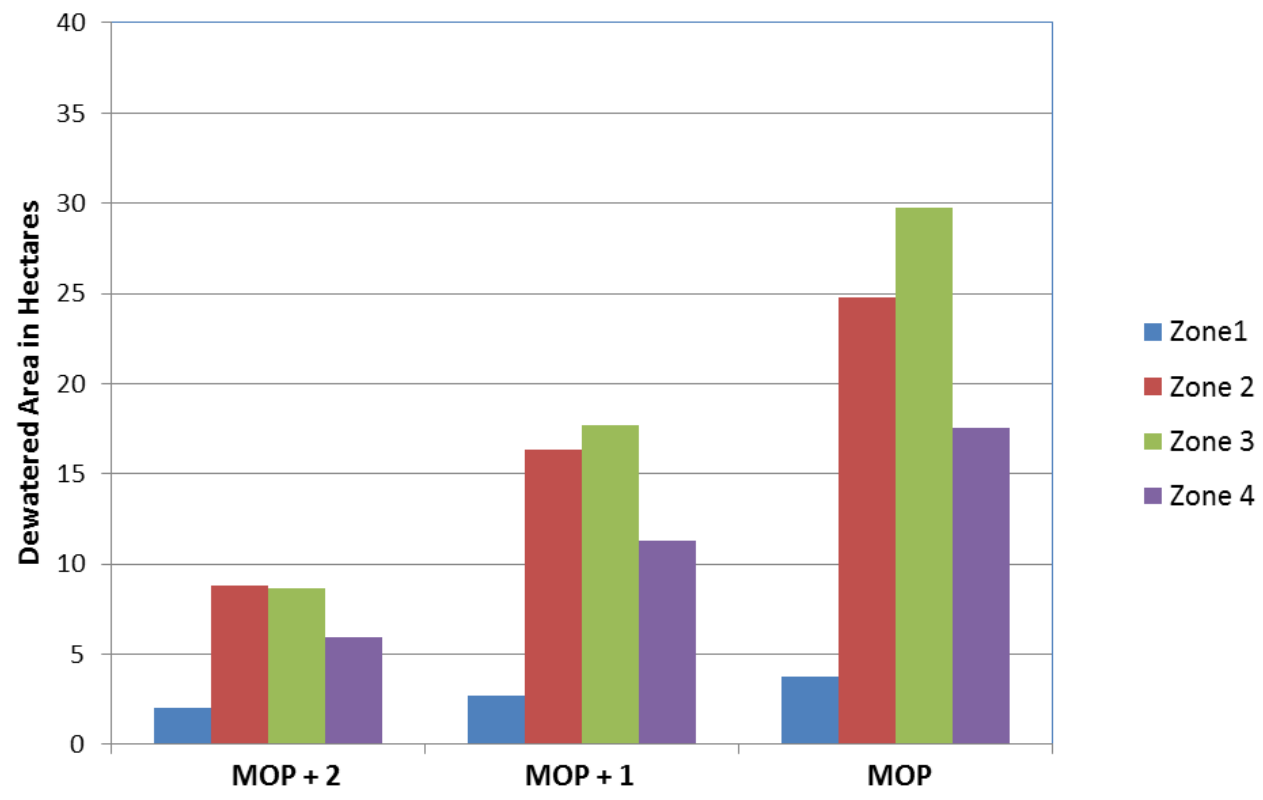

Figure 10. Change in hectares of inundation in the zones of interest for a river flow of $291 \mathrm{kcfs}$.

There are a few notable differences in the response to changing forebay elevation between flows. The area of inundation is much more sensitive to the Bonneville Dam forebay elevation at lower flows than at higher flows. Changing the forebay elevation at Bonneville Dam and the resulting impact on total dewatered regions was greater at the 97-kcfs river flow and showed the greatest variation at Zone 3 (White Salmon/Hood rivers) followed by Zones 2, 4, and 1. 
It should be noted that the areas of interest are those with little measured bathymetric data. The resulting data should be viewed as indicative of trends rather than an absolute measure. It is highly desirable to have much more accurate bathymetric data in the areas of interest. In addition, as lamprey habitat (substrate composition) needs become quantified, it would be possible to revisit these results and apply criteria such as velocity and/or depth to determine changes in areas of suitable habitat resulting from changes in project operations at The Dalles and Bonneville Dams. The areas delineated in this work could be modified or additional areas defined and analyzed in future work.

\subsection{Unsteady Model Outputs}

Because the Columbia River does not have constant or slowly varying flow in the Bonneville pool, MASS2 was run for a 2-week period from February 1 to 15 in 2002 to understand how inundation might change on a daily and hourly basis. This period in 2002 was selected due to large forebay WSE fluctuations. Initially, it appeared that a large spike in forebay elevation occurred during that period; however, the data were found to be incorrect when cross compared to other data sources. Figure 10 shows the total flow from The Dalles Dam (in red, secondary axis) and the WSE at Bonneville Dam. The WSE in the upstream pool closely follows that of the Bonneville Dam forebay with rapid changes of 1 to $2 \mathrm{ft}$ possible. The data show that 2.5-ft variation in WSE occurred during this period in 2002 and a 3.7-ft change occurred in 2014. The durations of these changes were variable and generally did not stay constant for more than a 5-hr period.

From the work discussed above, this can mean large changes in the very shallow areas near the tributary confluences of interest. The same period in 2014 is shown for comparison (Figure 11). The overall flows are lower, WSE in the Bonneville Dam forebay was generally higher, but the large hourly and daily fluctuations continue. Animations were produced for each of the four zones of interest for this 2-week period. The WSE at Bonneville Dam forebay for the maximum (74.8 ft) and minimum (72.2 ft) for the February 1 to15 in 2002 period for each of the zones are presented in Appendix A. 


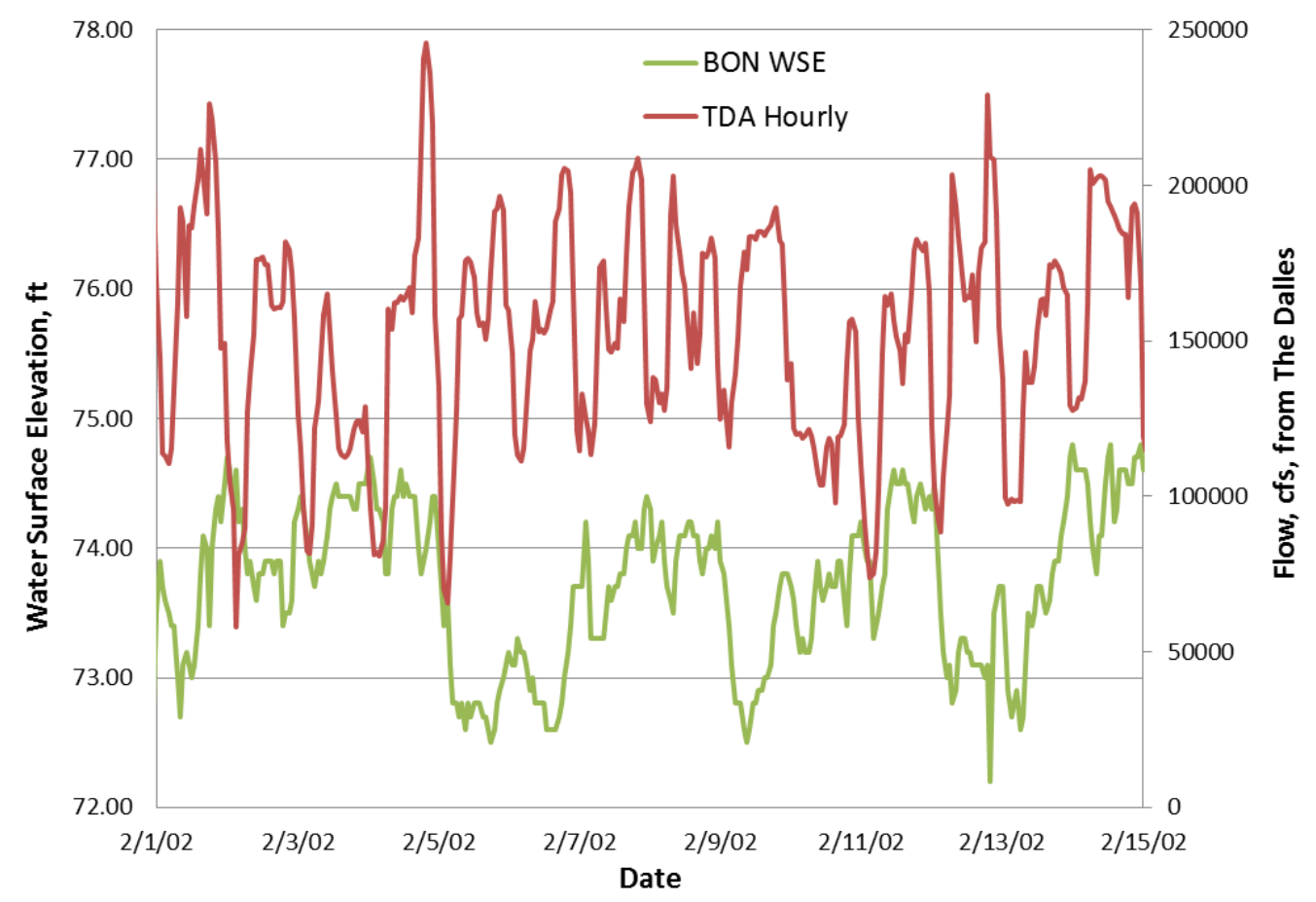

Figure 11. Unsteady MASS2 boundary conditions for Bonneville Dam (BON) WSE and The Dalles Dam (TDA) hourly flow from February 1 to 15 in 2002. 


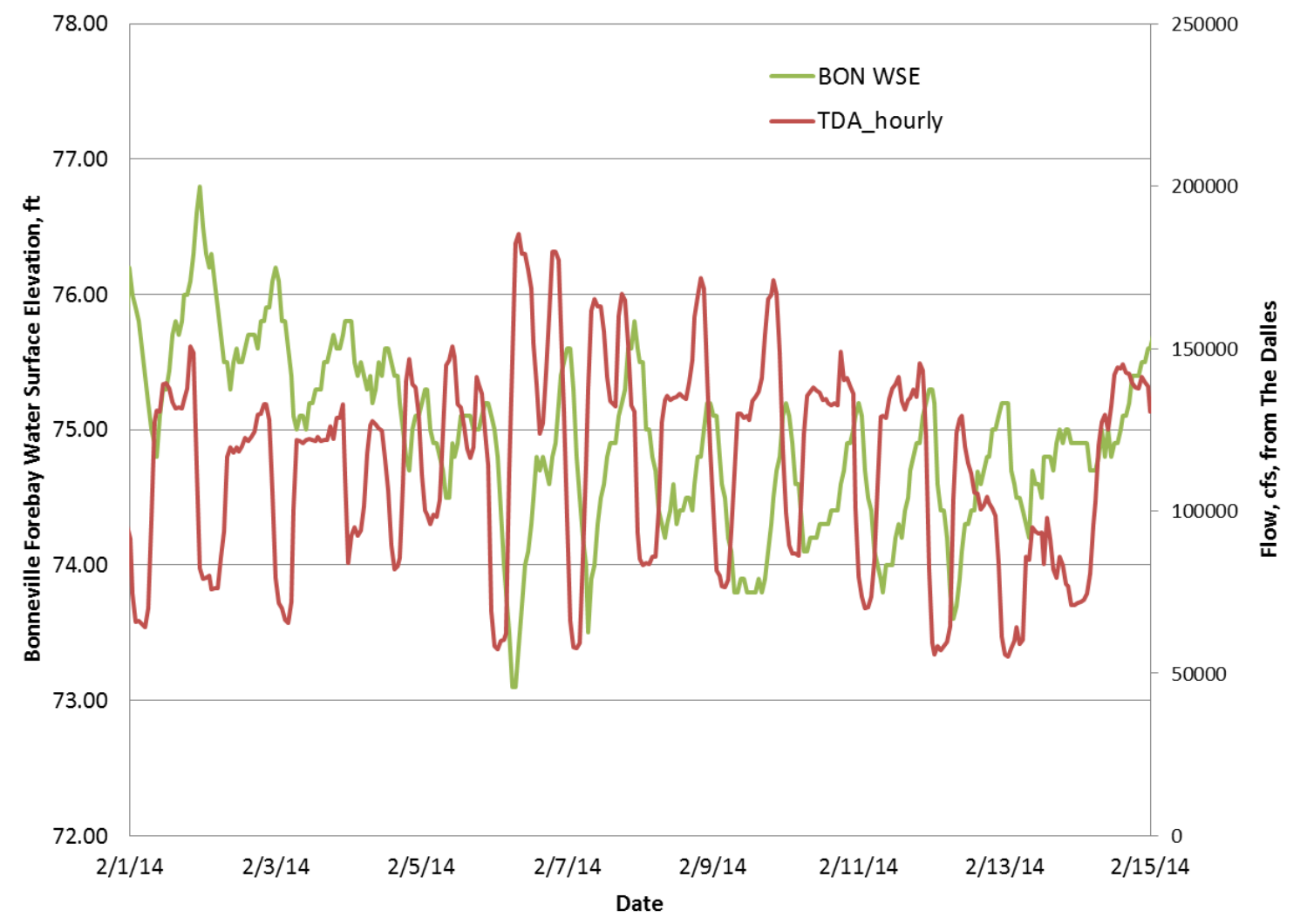

Figure 12. The Dalles Dam flows and Bonneville Dam forebay WSE for February 1 to 15 in 2014. 


\subsection{Discussion and Conclusions}

While the scope of this modeling effort was limited to the major tributaries confluences in the Bonneville pool, it provided a good starting point for developing a set of methods and identifying issues related to the use of the MASS2 numerical hydraulic model for lamprey habitat analysis purposes. Prior surveys in and near these regions have documented the presence of larval Pacific and Western Brook lamprey (Lampetra richardsonii) at various life stages. The regions at most risk can be classified and sampled using deepwater electrofishing gear to determine future impacts on lamprey rearing habitats. Additional studies are ongoing to determine impacts of desiccation on larval lampreys over extended periods, impacts of repeated dewatering events, and behavior related to flow ramping rates. Additional bathymetric measurements in the shallow areas in regions of concern are needed to improve the representation of habitats in MASS2 and to better classify substrate composition. This will allow the quantification of the change of habitat quantity and quality in response to the changing flows and project operations.

There are many constraints on the Columbia River hydrosystem operation. The recent addition of wind energy to the grid has increased the ever-changing demands on the hydrosystem to meet requirements and moderate the fluctuating inputs from wind power to the power grid; these demands will only increase over time. As such, meeting these demands may result in increases in river level fluctuations. During normal operations, the flow through The Dalles Dam is allowed to vary by $100 \mathrm{kcfs}$ in an hour (Dr. Laurie Ebner, CENWP, personal communication). The rate of change in the tailwater elevation at Bonneville Dam is one of the hydrosystem-wide requirements. Consequently, prior to when The Dalles Dam output is peaking, Bonneville Dam is drafting the forebay to accommodate the additional flow while still meeting the tailwater elevation requirements. These rapid changes in river flow at The Dalles Dam affect the forebay elevation at Bonneville Dam, and, presumably, throughout the pool, which contributes to dewatering along the shoreline and in the delta regions. There is a hydraulic control at Cascade Locks that contributes to the reduced sensitivity of the dewatered regions at higher flows in the four areas delineated for this study. These physical constraints indicate there is a complicated interplay of ever-changing river flows and project operations that affect the quality and quantity of juvenile lamprey habitat.

The MASS2 numerical hydraulic model used for this study indicated that the delta regions near the White Salmon and Hood Rivers would be most susceptible to WSE, which results in dewatering of sediments followed by the Wind, Klickitat, and the Little White Salmon rivers. The potential harm to rearing larval lampreys may include desiccation, forced movement to deeper water, and exposure to bird and fish predation. Tools such as the MASS2 model and a better understanding of habitat use can help elucidate the impacts of hydrosystem operations on larval lampreys. 


\subsection{References}

USACE (U.S. Army Corps of Engineers). 2009. Pacific Lamprey Passage Improvements Implementation Plan, 2008-2018, Final Report. Portland, Oregon.

Hanrahan TP, MC Richmond, EV Arntzen, AM Coleman, KB Larson, WA Perkins, and JD Tagestad. 2007. Effects of Hydroelectric Dam Operations on the Restoration Potential of Snake River Fall Chinook Salmon (Oncorhynchus tshawytscha) Spawning Habitat. Final Report, October 2005-September 2007, PNNL-16944, Pacific Northwest National Laboratory, Richland, Washington.

Johnson EL, TS Clabough, CA Peery, DH Bennett, TC Bjornn, CC Caudill, and MC Richmond. 2007. Estimating Adult Chinook Salmon Exposure to Dissolved Gas Supersaturation Downstream of Hydroelectric Dams Using Telemetry and Hydrodynamic Models. River Research and Applications 23(9):963-978.

Jolley JC, GS Silver, and TA Whitesel. 2012a. Occupancy and detection of larval Pacific LAMPREYS and Lampetra spp. in a large river: the Lower Willamette River. Transactions of the American Fisheries Society 141:305-312.

Jolley, JC, GS Silver, and TA Whitesel. 2012b. Occurrence, Detection, and Habitat Use of Larval Lamprey in Columbia River Mainstem Environments: Bonneville Tailwater and Tributary Mouths. 2011 Annual Report, U.S. Fish and Wildlife Service, Columbia River Fisheries Program Office, Vancouver, Washington.

Jolley, JC, GS Silver, and TA Whitesel. 2011. Occurrence, Detection, and Habitat Use of Larval Lamprey in Columbia River Mainstem Environments: Bonneville Reservoir and Tailwater. 2010 Annual Report, U.S. Fish and Wildlife Service, Columbia River Fisheries Program Office, Vancouver, Washington.

Kincaid CT, RW Bryce, PW Eslinger, JM Becker, CA Brandt, AL Bunn, CR Cole, EJ Freeman, GR Guensch, DG Horton, GV Last, TB Miley, WA Perkins, WE Nichols, M Oostrom, MC Richmond, DL Strenge, and PD Thorne. 2001. Development of a Site-Wide System Assessment Capability. Presented at the Waste Management 2001 Symposium, February 25 - March 1, 2001, sponsored by the University of Arizona, Tucson, Arizona.

McMichael GA, WA Perkins, CJ McMurray, YJ Chien, CL Rakowski, A Coleman, MC Richmond, J Vucelick, EV Arntzen, RP Mueller, CA Duberstein, and J Lukas. 2003. Subyearling Chinook Salmon Stranding in the Hanford Reach of the Columbia River. PNWD-3308, prepared for Grant County Public Utility District No. 2, Ephrata, Washington, by Battelle-Pacific Northwest Division, Richland, Washington.

Moser ML, AD Jackson, MC Lucas, and RP Mueller. 2014. Behavior and potential threats to survival of migrating lamprey ammocoetes and macrophthalmia. Reviews in Fish Biology and Fisheries. DOI: 10.1007/s11160-014-9372-8.

Niehus SE, WA Perkins, and MC. Richmond. 2014. Simulation of Columbia River Hydrodynamics and Water Temperature from 1917 through 2011 in the Hanford Reach. PNWD-3278, prepared for Public 
Utility District No. 2 of Grant County, Ephrata, Washington, by Battelle Pacific Northwest Division, Richland, Washington.

NPCC (Northwest Power and Conservation Council). 1994/95. Columbia Basin Fish and Wildlife Program, Section 7F. Portland, Oregon. http://www.nwcouncil.org/fw/program/94-55/

Patankar S. 1980. Numerical Heat Transfer and Fluid Flow. Hemisphere, New York, New York.

Perkins WA, MC Richmond, and GA McMichael. 2004. Two-Dimensional Modeling of Time-Varying Hydrodynamics and Juvenile Chinook Salmon Habitat in the Hanford Reach of the Columbia River. In Critical Transitions in Water and Environmental Resources Management, Proceedings of the 2004 World Water and Environmental Resources Congress, June 27-July 1, Salt Lake City, Utah, Reston, Virginia. Sehlke G, DF Hayes, and DK Stevens (eds.), ASCE: http://dx.doi.org/10.1061/40737(2004)180

Perkins WA and MC Richmond. 2004. MASS2, Modular Aquatic Simulation System in Two Dimensions, Theory and Numerical Methods. PNNL-14820-1, Pacific Northwest National Laboratory, Richland, Washington.

Rakowski CL, JA Serkowski, MC Richmond, and WA Perkins. 2010. Determining Columbia and Snake River Project Tailrace and Forebay Zones of Hydraulic Influence using MASS2 Modeling. PNNL-20030, Pacific Northwest National Laboratory, Richland, Washington.

Rakowski CL, WA Perkins, MC Richmond, and JA Serkowski. 2008. Determining John Day Project Tailrace and Forebay Zones Using the MASS2 Model. PNNL-SA-60840, Pacific Northwest National Laboratory, Richland, Washington.

Rakowski CL and MC Richmond. 2001. Dalles Tailwater Predator Study: Numerical Analysis of Tailwater Flow Conditions. PNNL-13594, Pacific Northwest National Laboratory, Richland, Washington.

Rakowski CL and MC Richmond. 2003. John Day Tailrace MASS2 Hydraulic Modeling. PNNL-14491, Pacific Northwest National Laboratory, Richland, Washington.

Richmond MC and WA Perkins. 2009. Efficient Calculation of Dewatered and Entrapped Areas Using Hydrodynamic Modeling and GIS. Environmental Modelling \& Software 24:1447-1456.

http://dx.doi.org/10.1016/j.envsoft.2009.06.001

Richmond MC, WA Perkins, and Y Chien. 2000. Numerical Model Analysis of System-wide Dissolved Gas Abatement Alternatives. PNWD-3245, prepared for the U.S. Army Corps of Engineers, Portland and Walla Walla Districts, by Battelle-Pacific Northwest Division, Richland, Washington.

Richmond MC, WA Perkins, and TD Scheibe. 1999a. Two-Dimensional Hydrodynamic, Water Quality, and Fish Exposure Modeling of the Columbia and Snake Rivers. Proceedings of the Water Power Conference 1999, Las Vegas, Nevada. http://dx.doi.org/10.1061/40440(1999)48.

Richmond MC, WA Perkins, and CL Rakowski. 1999b. Two-Dimensional Analysis of Flow Conditions and Sediment Mobility in the Lower Snake River for Impounded and Natural River Conditions. Prepared 
for the U.S. Army Corps of Engineers, Walla Walla District, by Pacific Northwest National Laboratory, Richland, Washington.

Spasojevic M and F Holly, Jr. 1990. 2-D Bed Evolution in Natural Watercourses New Simulation Approach. Journal of Waterway, Port, Coastal, and Ocean Engineering 116(4):425-443.

Zhou J. 1995. Velocity-Depth Coupling in Shallow-Water Flows. Journal of Hydraulic Engineering 121(10):717-724. 

Appendix A

Modeled Riverbed Elevations 



\section{Appendix A}

\section{Modeled Riverbed Elevations}

The ensuing figures present the modeled riverbed elevations derived using unsteady MASS2

boundaries for river flow measured at The Dalles Dam from February 1-15, 2002. They illustrate the resulting maximum (74.8 ft) and minimum (72.2 ft) elevations as measured at the Bonneville Dam forebay. 


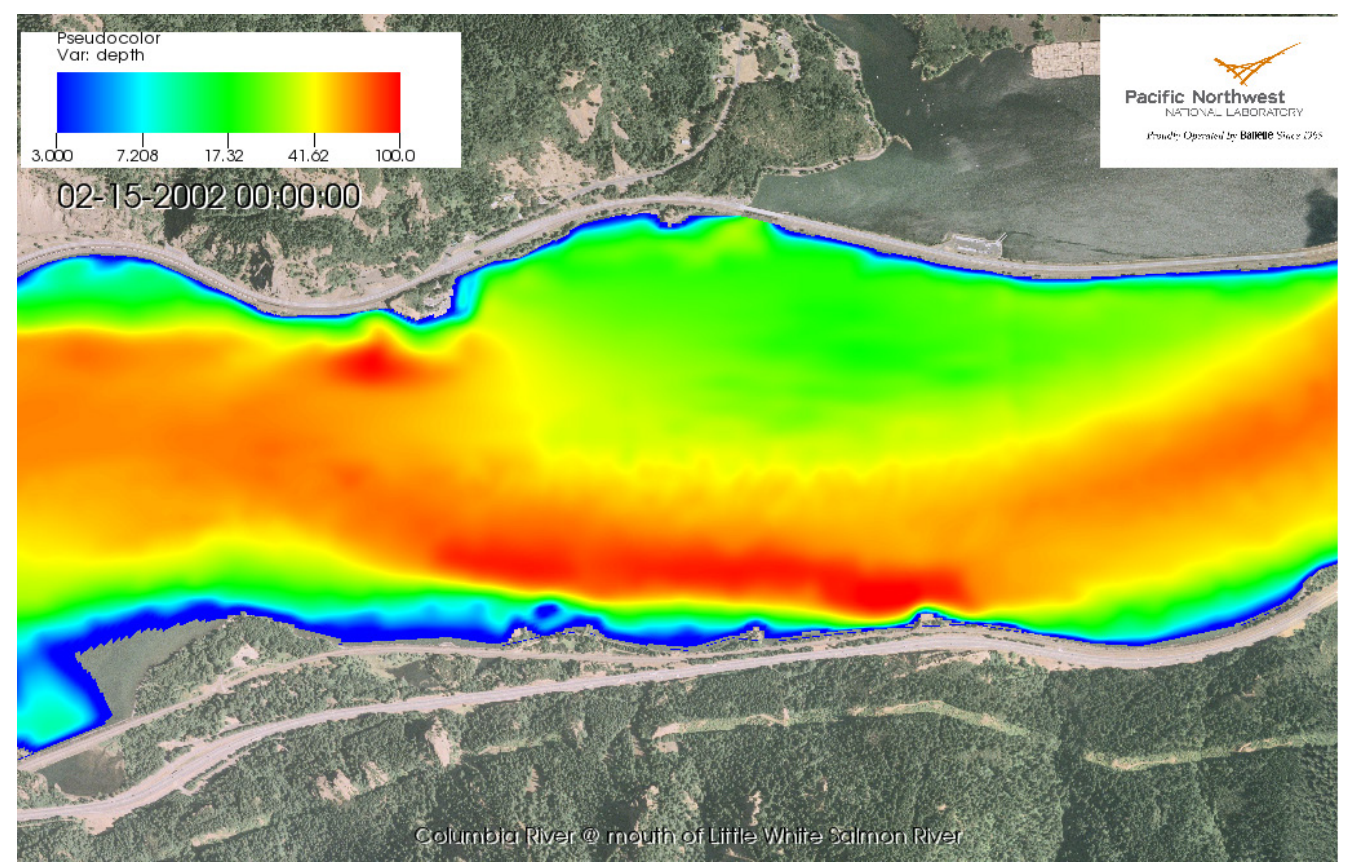

b

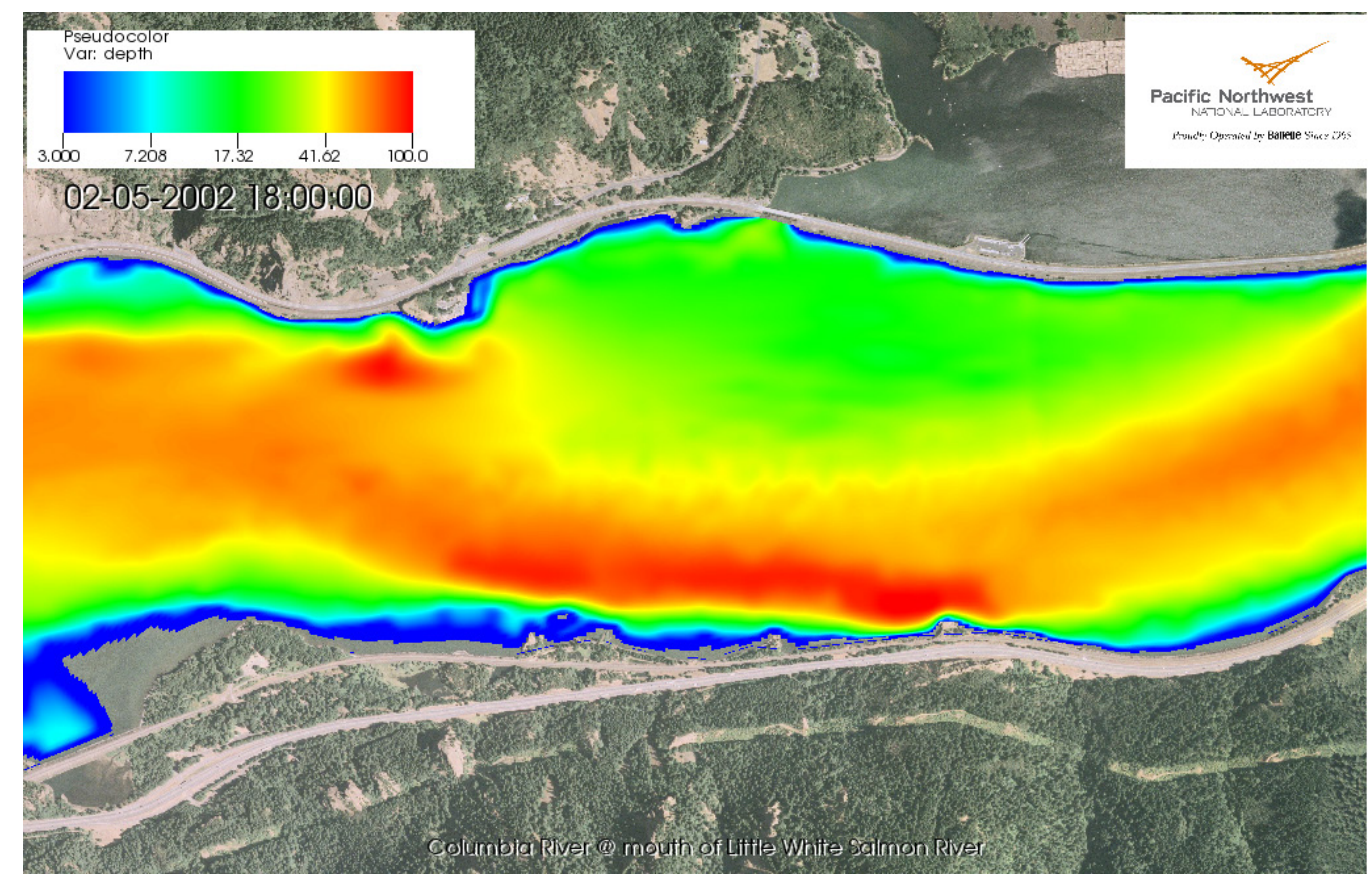

Figure A.1. Little White Salmon River-Zone 1 a) maximum (74.8 ft) and b) minimum (72.2 ft) elevations as measured at Bonneville Dam forebay. 

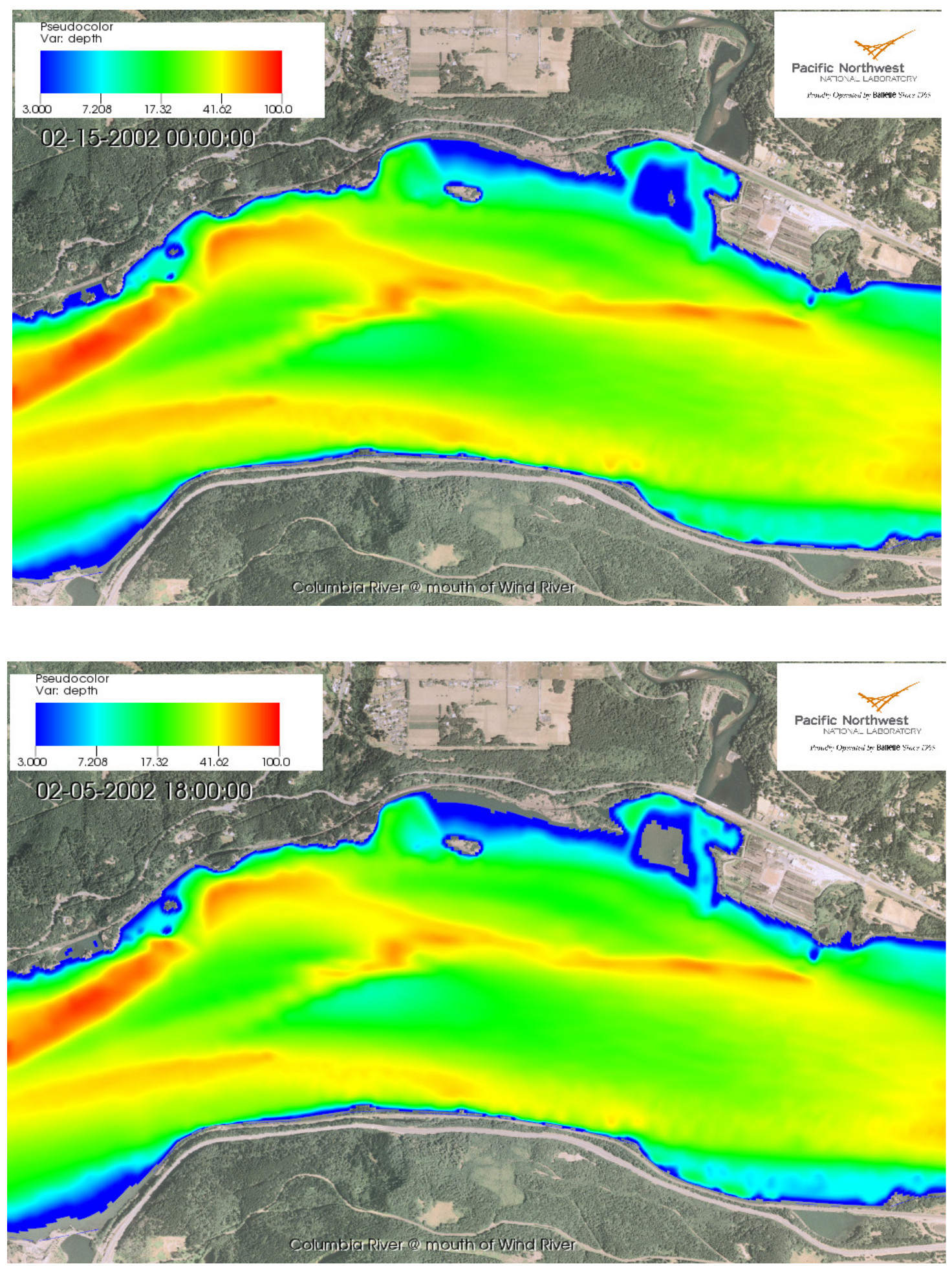

Figure A.2. Wind River - Zone 2, a) maximum (74.8 ft) and b) minimum (72.2 ft) elevations as measured at Bonneville Dam forebay. 


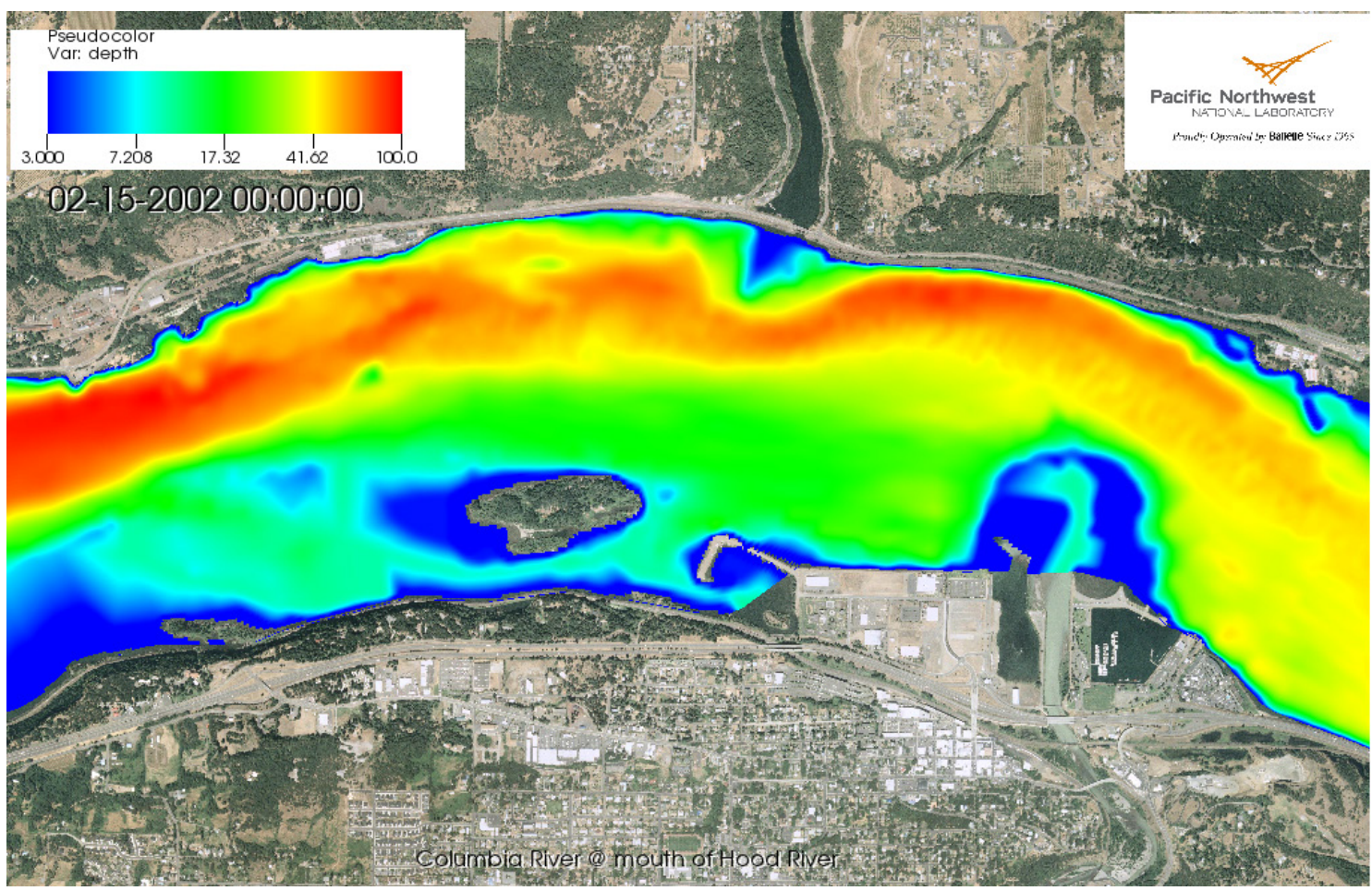

b

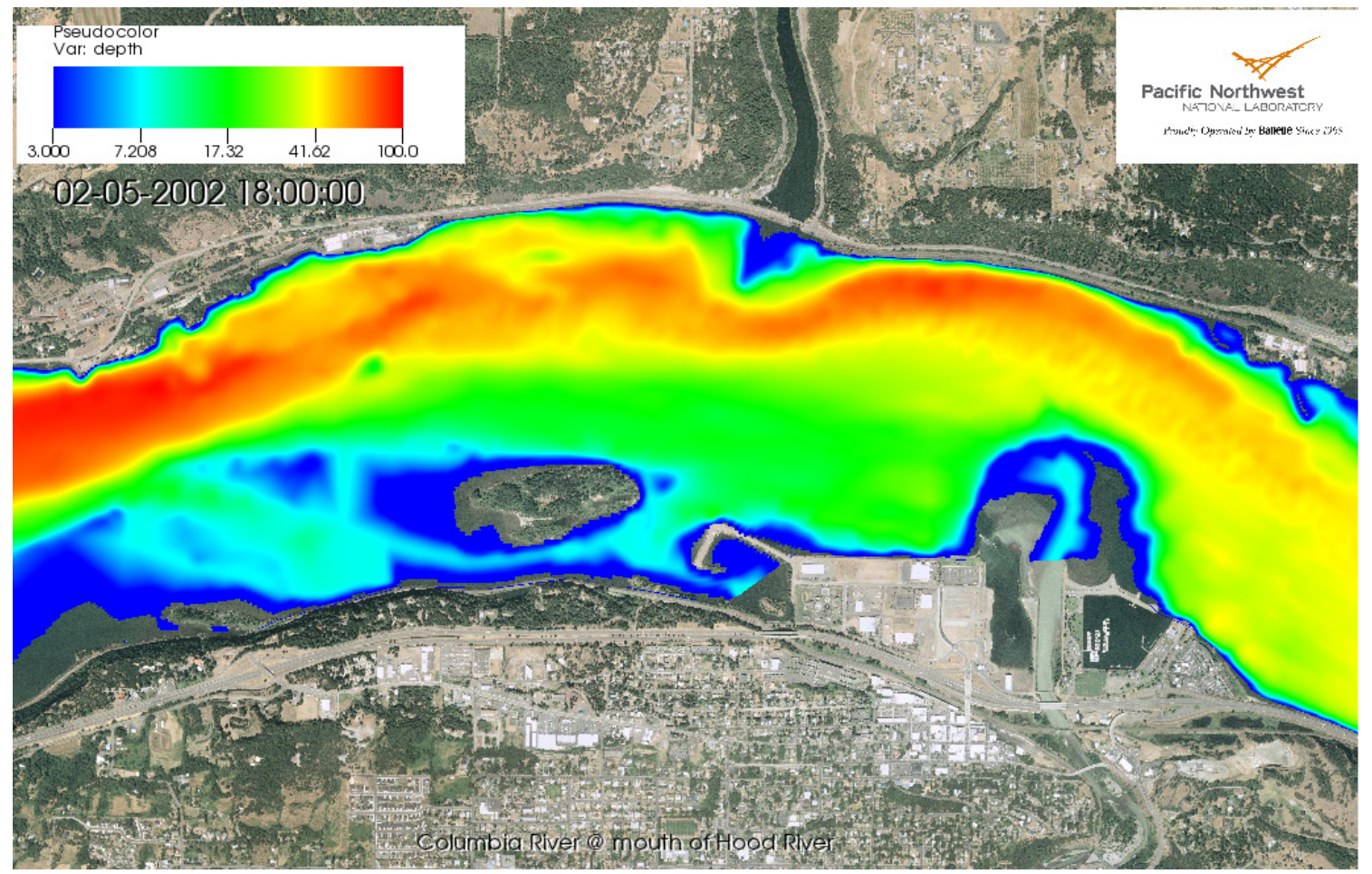

Figure A.3. White Salmon/Hood rivers, Zone 3, a) maximum (74.8 ft) and b) minimum (72.2 ft) elevations as measured at Bonneville Dam forebay. 


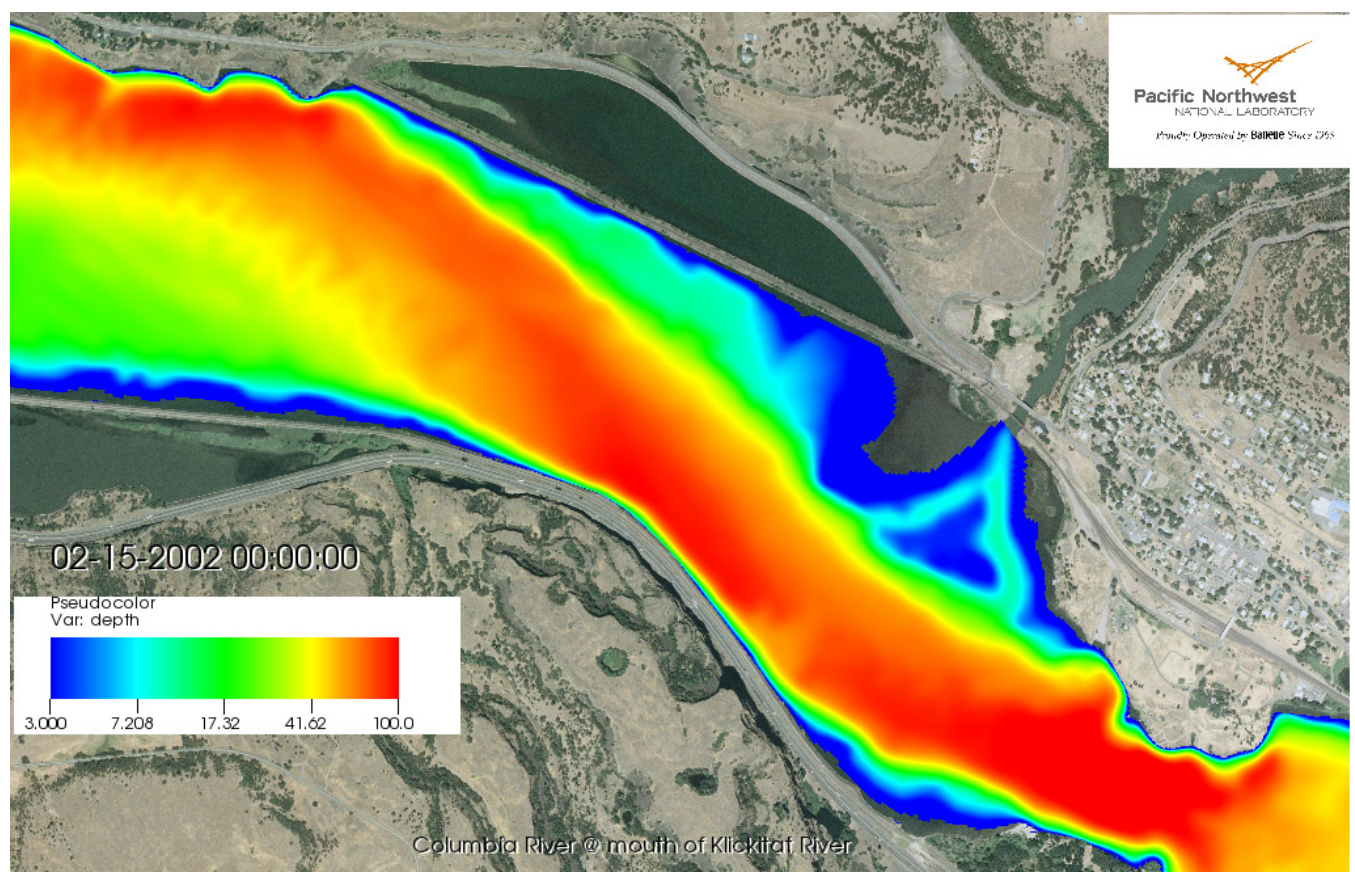

b

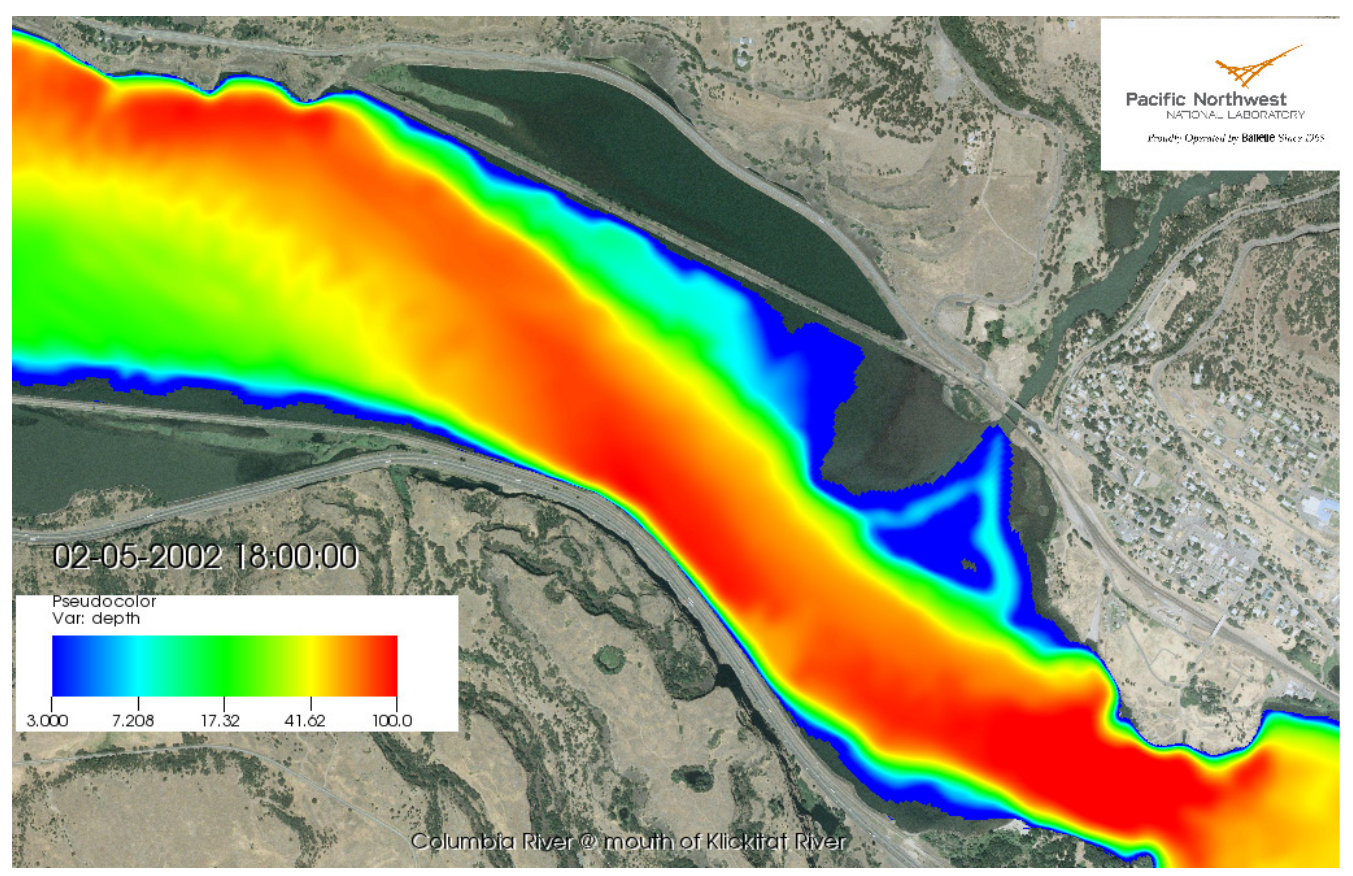

Figure A.4. Klickitat River - Zone 4, a) maximum (74.8 ft) and b) minimum (72.2 ft) elevations as measured at Bonneville Dam forebay. 



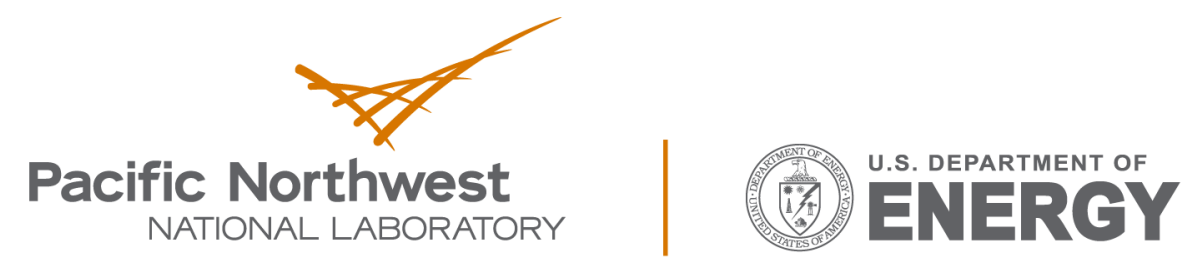

Proudly Operated by Battelle Since 1965

902 Battelle Boulevard

P.O. Box 999

Richland, WA 99352

1-888-375-PNNL (7665)

www.pnnl.gov 